Prepared in cooperation with the Arkansas Natural Resources Commission and the Arkansas Geological Survey

\title{
Potentiometric Surfaces and Water-Level Trends in the Cockfield and Wilcox Aquifers of Southern and Northeastern Arkansas, 2006
}

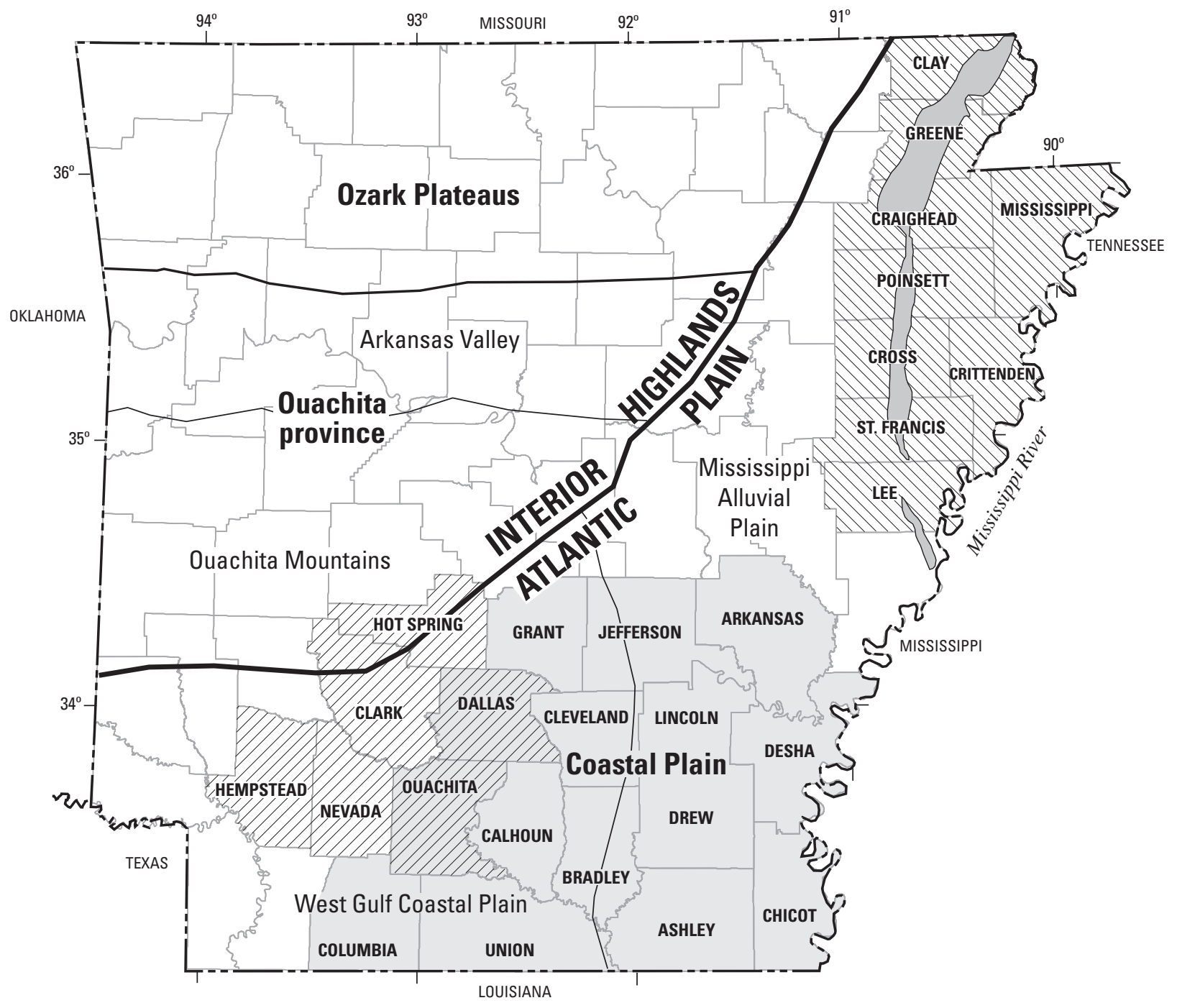

Scientific Investigations Report 2007-5218

U.S. Department of the Interior

U.S. Geological Survey 


\section{Potentiometric Surfaces and Water- Level Trends in the Cockfield and Wilcox Aquifers of Southern and Northeastern Arkansas, 2006}

By T.P. Schrader

In cooperation with the Arkansas Natural Resources Commission and

the Arkansas Geological Survey

Scientific Investigations Report 2007-5218 


\section{U.S. Department of the Interior DIRK KEMPTHORNE, Secretary}

\section{U.S. Geological Survey \\ Mark D. Myers, Director}

\section{U.S. Geological Survey, Reston, Virginia: 2007}

For product and ordering information:

World Wide Web: http://www.usgs.gov/pubprod

Telephone: 1-888-ASK-USGS

For more information on the USGS--the Federal source for science about the Earth, its natural and living resources, natural hazards, and the environment:

World Wide Web: http://www.usgs.gov

Telephone: 1-888-ASK-USGS

Any use of trade, product, or firm names is for descriptive purposes only and does not imply endorsement by the U.S. Government.

Although this report is in the public domain, permission must be secured from the individual copyright owners to reproduce any copyrighted materials contained within this report.

Suggested citation:

Schrader, T.P., 2007, Potentiometric surfaces and water-level trends in the Cockfield and Wilcox aquifers of southern and northeastern Arkansas, 2006: U.S. Geological Survey Scientific Investigations Report 2007-5218, 27 p. 


\section{Contents}

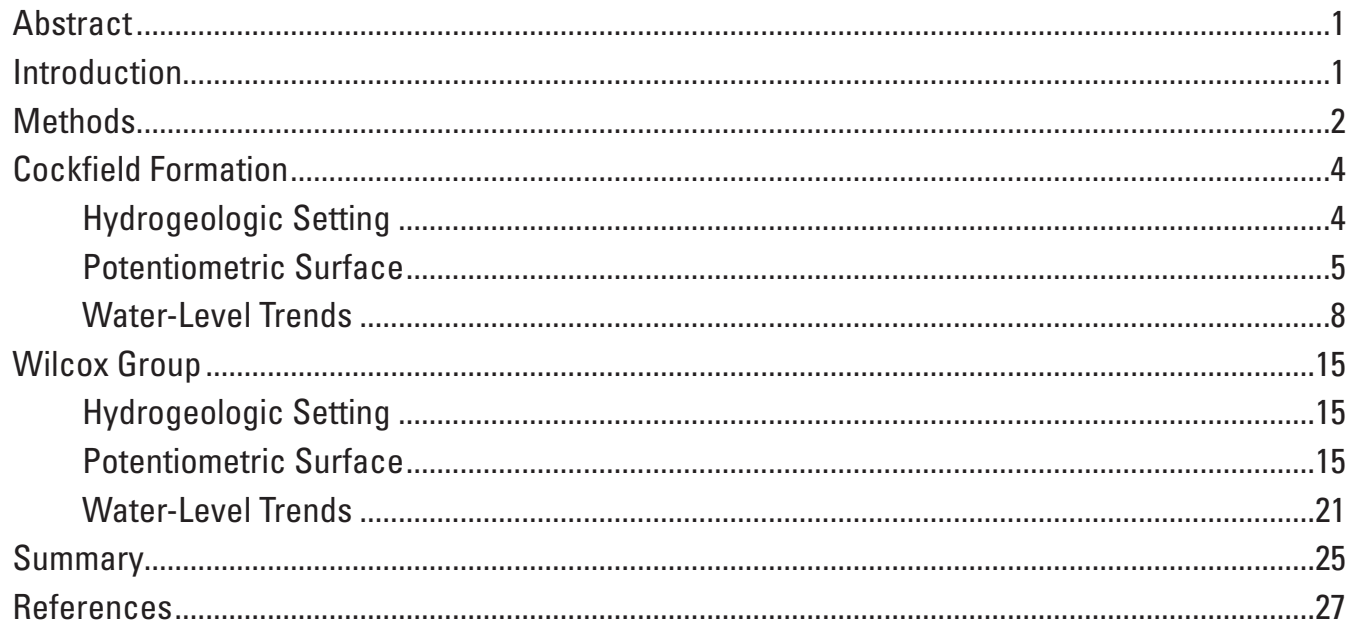

\section{Figures}

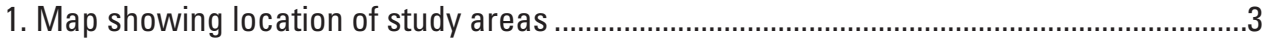

2. Diagram showing well-numbering system ....................................................................

3. Graphs showing water use from the Cockfield aquifer, $1975-2000 \ldots \ldots \ldots \ldots \ldots \ldots \ldots \ldots \ldots \ldots \ldots \ldots \ldots . . . .4$

4. Map showing potentiometric surface of the Cockfield aquifer in southeastern

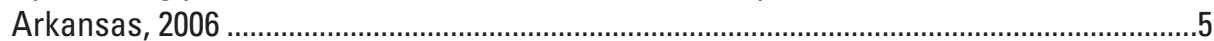

5. Water-level hydrographs for selected wells completed in the Cockfield aquifer in

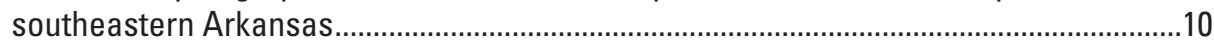

6. Graph showing water use from the Wilcox aquifer, 1975-2000 …....................................15

7. Map showing potentiometric surface of the Wilcox aquifer in southern Arkansas,

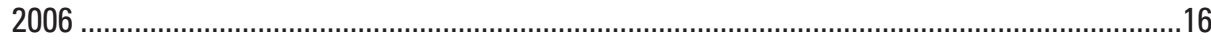

8. Map showing potentiometric surface of the Wilcox aquifer in northeastern Arkansas, 2006

9. Water-level hydrographs for selected wells completed in the Wilcox aquifer in northeastern Arkansas.

\section{Tables}

1. Water-level data collected from wells completed in the Cockfield aquifer in southeastern Arkansas, 2006

2. Range, mean, and median of annual rise/decline in water level by county for wells in the aquifer, 1986-2006

3. Water-level data collected from wells completed in the Wilcox aquifer in southwestern Arkansas, 2006

4. Water-level data collected from wells completed in the Wilcox aquifer in northeastern Arkansas, 2006

5. Range, mean, and median of annual rise/decline in water level by county for wells in the Wilcox aquifer in the northeastern study area, 1986-2006. 


\section{Conversion Factors and Datums}

\begin{tabular}{lcl}
\hline \multicolumn{1}{c}{ Multiply } & By & \multicolumn{1}{c}{ To obtain } \\
\hline foot $(\mathrm{ft})$ & Length & \\
mile $(\mathrm{mi})$ & 0.3048 & meter $(\mathrm{m})$ \\
& 1.609 & kilometer $(\mathrm{km})$ \\
\hline foot per year $(\mathrm{ft} / \mathrm{yr})$ & Flow rate & \\
gallon per minute $(\mathrm{gal} / \mathrm{m})$ & 0.3048 & meter per year $(\mathrm{m} / \mathrm{yr})$ \\
million gllons per day $(\mathrm{Mgal} / \mathrm{d})$ & 0.6308 & liter per second $(\mathrm{L} / \mathrm{s})$ \\
\hline
\end{tabular}

Temperature in degrees Celsius $\left({ }^{\circ} \mathrm{C}\right)$ may be converted to degrees Fahrenheit $\left({ }^{\circ} \mathrm{F}\right)$ as follows: ${ }^{\circ} \mathrm{F}=\left(1.8 \mathrm{x}{ }^{\circ} \mathrm{C}\right)+32$ Vertical coordinate information is referenced to the National Geodetic Vertical Datum of 1929 (NGVD of 1929).

Horizontal coordinate information is referenced to the North American Datum of 1983 (NAD of 1983). 


\title{
Potentiometric Surfaces and Water-Level Trends in the Cockfield and Wilcox Aquifers of Southern and Northeastern Arkansas, 2006
}

\author{
By T.P. Schrader
}

\section{Abstract}

The Cockfield Formation of Claiborne Group and the Wilcox Group contain aquifers that provide sources of ground water in southern and northeastern Arkansas. In 2000, about 9.9 million gallons per day was withdrawn from the Cockfield Formation of Claiborne Group and about 22.2 million gallons per day was withdrawn from the Wilcox Group. Major withdrawals from the aquifers were for industrial and public water supplies.

A study was conducted by the U.S. Geological Survey in cooperation with the Arkansas Natural Resources Commission and the Arkansas Geological Survey to determine the water level associated with the aquifers in the Cockfield Formation of Claiborne Group and the Wilcox Group in southern and northeastern Arkansas. During February and March 2006, 56 water-level measurements were made in wells completed in the Cockfield aquifer and 59 water-level measurements were made in wells completed in the Wilcox aquifer, 16 in southwestern and 43 in northeastern Arkansas. This report presents the results as potentiometric-surface maps and as long-term water-level hydrographs.

The regional direction of ground-water flow in the Cockfield Formation of Claiborne Group generally is towards the east and southeast, away from the outcrop, except in areas of intense ground-water withdrawals, such as western Drew County, southeastern Lincoln County, southwestern Calhoun County, and near Crossett in Ashley County. There are three cones of depression indicated by relatively low water-level altitudes in southeastern Lincoln County, southwestern Calhoun County, and near Crossett in Ashley County. The lowest water-level altitude measured was 44 feet above the National Geodetic Vertical Datum of 1929 in Lincoln County; the highest water-level altitude measured was 346 feet above the National Geodetic Vertical Datum of 1929 in Columbia County at the outcrop area. Hydrographs from 40 wells with historical water levels from 1986 to 2006 were evaluated using linear regression to calculate the annual rise or decline. Calhoun and Cleveland Counties have mean annual rises from
0.01 to 0.07 feet per year. Arkansas, Ashley, Bradley, Chicot, Columbia, Drew, Lincoln, and Union Counties have mean annual declines from 0.4 to 0.55 feet per year. Desha County has a mean annual decline of about 1.35 feet per year.

The direction of ground-water flow in the southwestern study area of the Wilcox Group generally is south and east. The lowest water-level altitude measured in southwestern Arkansas was 147 feet above the National Geodetic Vertical Datum of 1929 near the Ouachita River in Clark County; the highest water-level altitude measured was 397 feet above the National Geodetic Vertical Datum of 1929 in the outcrop area of Hempstead County. The direction of ground-water flow in the northeastern study area of the Wilcox Group generally is south and east. The lowest water-level altitude measured in northeastern Arkansas was 120 feet above the National Geodetic Vertical Datum of 1929 near West Memphis in Crittenden County; the highest water-level altitude measured was 368 feet above the National Geodetic Vertical Datum of 1929 on Crowleys Ridge in Clay County. Hydrographs from 28 wells with historical water levels from 1986 to 2006 were evaluated using linear regression to calculate the annual rise or decline. All 28 wells showed an annual decline from 1986 to 2006. Craighead, Greene, Mississippi, and Poinsett Counties have mean annual declines from 0.27 to 1.00 feet per year. Crittenden, Lee, and St. Francis Counties have mean annual declines from 1.39 to 1.64 feet per year.

\section{Introduction}

The Cockfield Formation of Claiborne Group and the Wilcox Group contain aquifers that provide sources of ground water in southern and northeastern Arkansas, where in 2000 about 9.9 million gallons per day (Mgal/d) was withdrawn from the Cockfield Formation of Claiborne Group and about 22.2 Mgal/d was withdrawn from the Wilcox Group (Holland, 2004). Major withdrawals from the aquifers were for industrial and public water supplies, with lesser but locally important withdrawals for domestic and livestock uses. 
A study was conducted by the U.S. Geological Survey (USGS) in cooperation with the Arkansas Natural Resources Commission and the Arkansas Geological Survey to determine the water level associated with the aquifers in the Cockfield Formation of Claiborne Group and the Wilcox Group (hereafter the respective aquifers are referred to as the Cockfield aquifer and the Wilcox aquifer) in southern and northeastern Arkansas. During February and March 2006, 56 water-level measurements were made in wells completed in the Cockfield aquifer and 59 water-level measurements were made in wells completed in the Wilcox aquifer, 16 in southwestern and 43 in northeastern Arkansas. This report presents the results as potentiometric-surface maps and as long-term water-level hydrographs.

The study areas of the Cockfield and Wilcox aquifers (fig. 1) include much of the West Gulf Coastal Plain and the Mississippi Alluvial Plain in Arkansas. The study area of the Cockfield aquifer in southeastern Arkansas is bounded on the east by the Mississippi River and on the south by the Louisiana State line. The western boundary is defined by the western extent of the outcrop and subcrop (Hosman, 1982) of the Cockfield Formation. The northern boundary is defined by the locations of observation wells. The study area boundary of the Wilcox aquifer in southwestern Arkansas is defined by the outcrop of the Wilcox Group and the locations of observation wells in Clark, Hempstead, Hot Spring, Nevada, and Ouachita Counties. The study area of the Wilcox aquifer in northeastern Arkansas is bounded on the north by the Missouri State line and on the east by the Mississippi River. The western and southern boundaries of the study area are defined by the extent of the outcrop at or near Crowleys Ridge, and by the location of observation wells that penetrate the Wilcox aquifer.

This report is the fourth in a triennial series of reports discussing the potentiometric surfaces of the Cockfield and Wilcox aquifers. Earlier reports in 2003, 2000, and 1996-1997 can be referenced through Yeatts (2004), Schrader and Joseph (2000), and Joseph (1998), respectively. The potentiometric surfaces for 1991 were published in a map report (Westerfield, 1994). In the report by Yeatts (2004), 55 and 56 wells completed in the Cockfield and Wilcox aquifers, respectively, were measured for water levels.

\section{Methods}

The well-numbering system used in this report is based upon the location of the wells according to the Public Land Survey System used in Arkansas. The component parts of a well number are the township number, the range number, the section number, three letters which indicate, respectively, the quarter section, the quarter-quarter section, and the quarterquarter-quarter section in which the well is located, and a sequence number. The letters are assigned counterclockwise, beginning with "A" in the northeast quarter or quarter-quarter or quarter-quarter-quarter section in which the well is located.
For example, well 01S03W04BBD16 (fig. 2) is located in Township 1 South, Range 3 West, and in the southeast quarter of the northwest quarter of the northwest quarter of section 4 . This well is the 16th well in this quarter-quarter-quarter section of section 4 from which data were collected.

The horizontal coordinate information of wells was determined using a global positioning system (GPS) referenced to the North American Datum of 1983 (NAD 83), with accuracy to about one-tenth of a second of latitude and longitude (approximately 10-20 feet). The vertical coordinate information was determined with accuracy to about 5 feet (ft) from topographic maps referenced to the National Geodetic Vertical Datum of 1929 (NGVD of 1929). Herein all altitudes are referenced to NGVD of 1929.

Water levels were measured by USGS personnel at public water supply, industrial, commercial, domestic, and observation wells open to the Cockfield or Wilcox aquifers. Water levels were measured at least 1 hour after pumping from the well had ceased. Measurements were recorded after consecutive measurements, with a 5-minute interval, differed by no more than $0.02 \mathrm{ft}$. Measurements were made using steel or electric tapes graduated to hundredths of a foot. The steel and electric tapes used by USGS personnel were calibrated during January 2006 prior to collecting measurements from wells. Calibration of steel and electric tapes was performed by comparing the field steel or electric tape to a standardized steel tape used only for calibration of field tapes.

There are five assumptions associated with linear regression: (1) Y is linearly related to $\mathrm{X}$, (2) data used to fit the linear regression are representative of data of interest, (3) variance of the residuals is constant and does not depend on $\mathrm{X}$ or on anything else, (4) the residuals are independent, and (5) the residuals are normally distributed. The assumption of a normal distribution is involved only when testing hypotheses, requiring the residuals from the regression equation to be normally distributed (Helsel and Hirsch, 1992).

Linear regression can be used with a hydrograph of water level versus time to calculate the annual rise or decline in water level. Another method for calculating the annual rise or decline is to take the difference between the final and initial water levels and divide by the period of time. This method is determined from two measurements and calculated values are dependent solely on the final and initial water levels. Linear regression includes all the measurements to determine the trend line, resulting in a value that is dependent on all water levels during the period of record. The slope, $\beta_{1}$, of the line is the annual rise or decline in water level. The intercept, $\beta_{0}$, would be the water level in the year 1900, the origin for the graph. This requires the assumption that the pumping rate would be constant throughout the period of pumping. This condition is not commonly met or the data are not available to demonstrate that this has occurred. The predevelopment water level will not be discussed as this condition can not be demonstrated. The $\mathrm{R}^{2}$ term is used as an indicator of the variability of the water-level data. Values of $\mathrm{R}^{2}$ can range from 0.00 to 1.00 . 


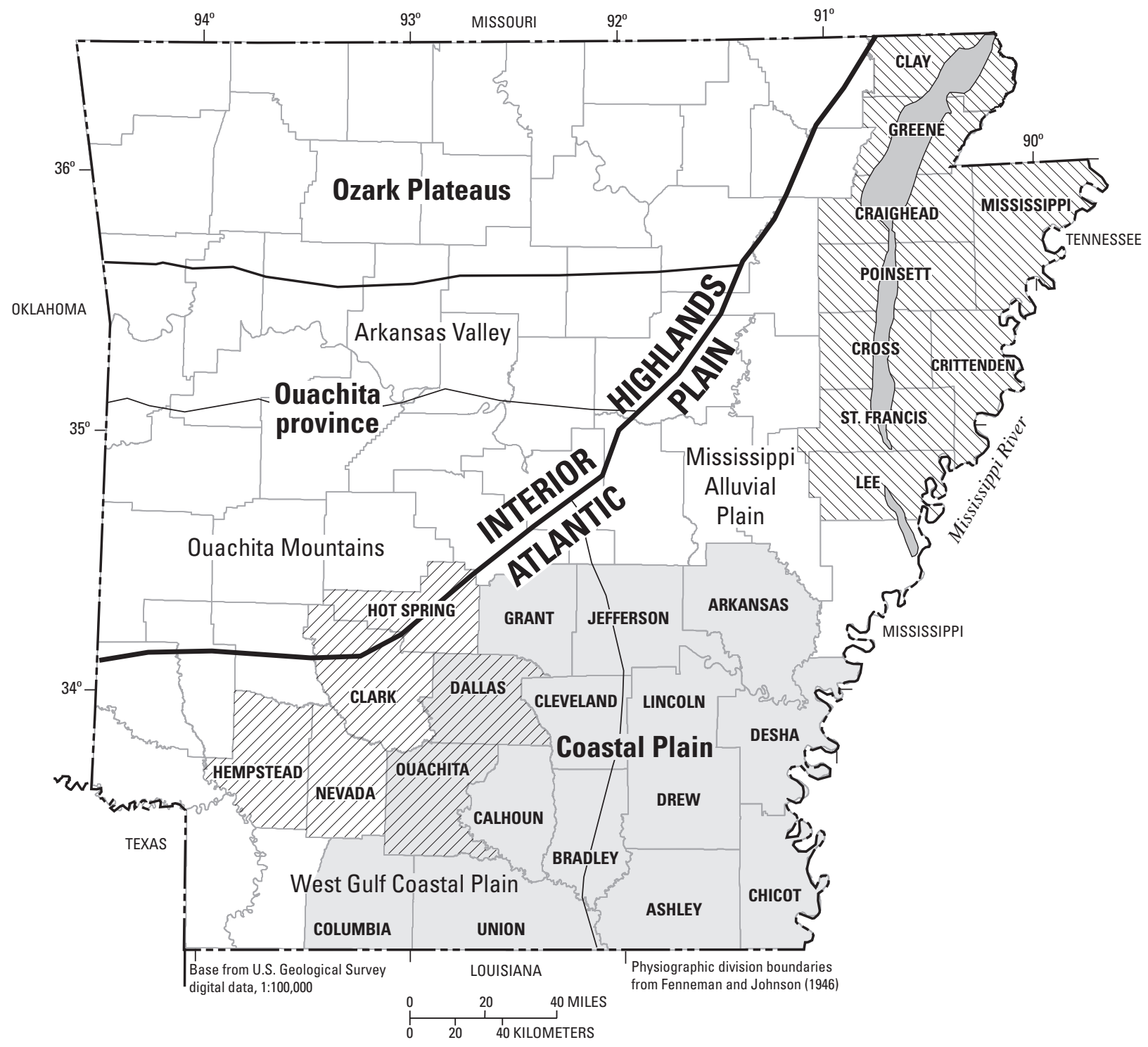

\section{EXPLANATION}

Study areas

Cockfield aquifer in southeastern Arkansas

VIA Wilcox aquifer in southwestern Arkansas

MII Wilcox aquifer in northeastern Arkansas
Crowley Ridge

Physiographic division boundary

Major Division

Province

Section

Figure 1. Location of study areas. 
A high value of $\mathrm{R}^{2}$ can indicate a linear change in water level. A low value of $\mathrm{R}^{2}$ can indicate sporadic change in water level.

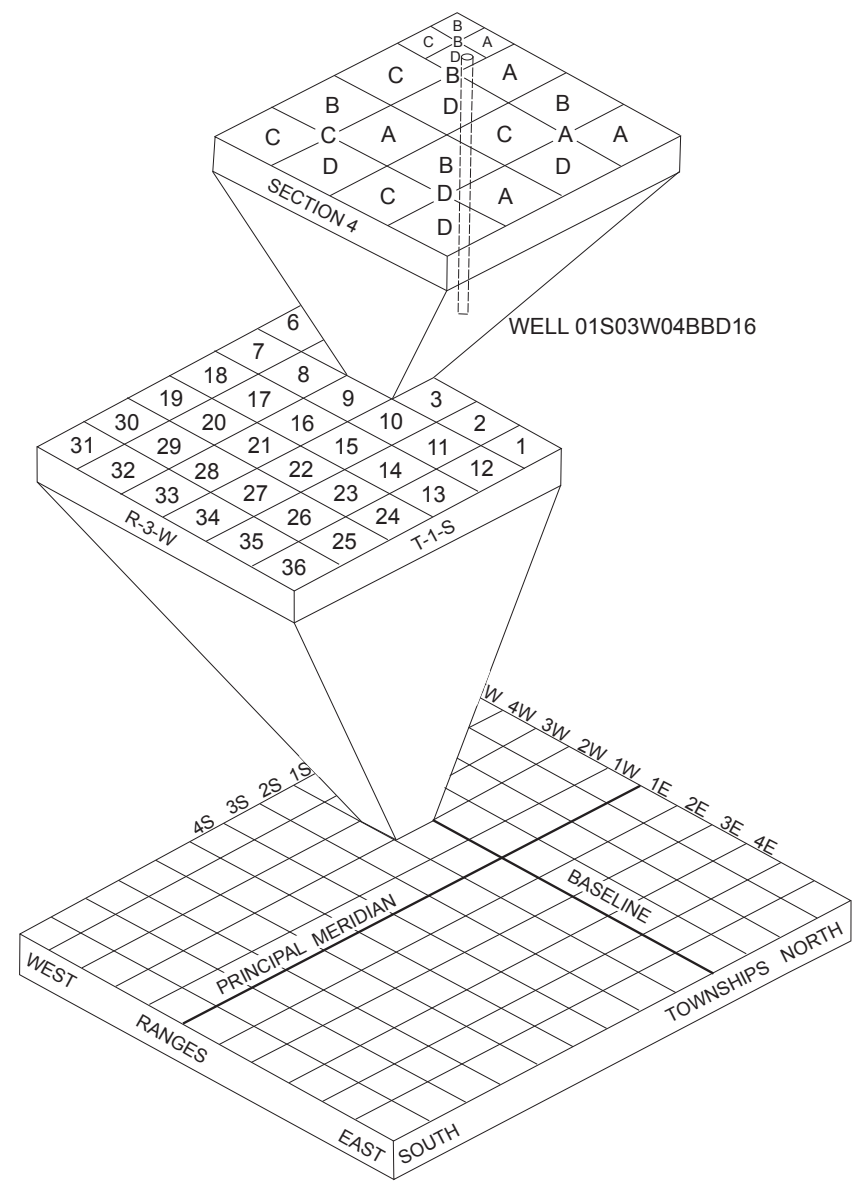

Figure 2. Well-numbering system.

\section{Cockfield Formation}

\section{Hydrogeologic Setting}

The Cockfield Formation of Claiborne Group (hereafter referred to as the Cockfield Formation) is Eocene age and generally consists of discontinuous fine- to medium-grained sand units interbedded with silt, clay, and lignite, all of nonmarine origin, in southeastern Arkansas. Most of the sand beds constitute the Cockfield aquifer and are found near the base of the Cockfield Formation. The Cockfield Formation generally ranges from 100 to $400 \mathrm{ft}$ thick near the outcrop area and thickens downdip of the outcrop area reaching 625 $\mathrm{ft}$ thick in northeastern Chicot County (Onellion and Criner, 1955). Total sand thickness in the Cockfield Formation generally ranges from 20 to $150 \mathrm{ft}$. The Cockfield Formation is underlain throughout the study area by calcareous and sandy marl, limestone, and carbonaceous clay of the Cook Mountain
Formation of Claiborne Group. The Cockfield Formation is overlain by silty clays of the Jackson Group throughout much of southeastern Arkansas. In the confined part of the aquifer, the potentiometric surface can be near or above land surface. Sand beds at the base of the overlying Jackson Group in parts of southeastern Arkansas may be in hydraulic connection with the Cockfield aquifer (Ackerman, 1987). The Cockfield aquifer comprises the water-yielding strata within the Cockfield Formation.

The Cockfield Formation outcrops in Grant, Dallas, Cleveland, Calhoun, Bradley, Columbia, and Union Counties and dips southeastward. In the subcrop area, the Cockfield Formation is overlain by terrace deposits and alluvium of Quaternary age. The terrace deposits may attain a thickness of $40 \mathrm{ft}$, and as much as $60 \mathrm{ft}$ of alluvium overlies the Cockfield Formation in some of the larger river valleys.

Most recharge to the Cockfield aquifer occurs by infiltration of rainfall on the upland outcrop areas and by inflow from the overlying alluvium; most discharge is to rivers in outcrop areas, to vertically adjacent units where the Cockfield aquifer is confined, and to wells (Ackerman, 1987). Well depths are shallow and yields of most wells in the outcrop areas are small, less than 30 gallons per minute (gal/min), but in other areas downdip of the outcrop, wells screened the full thickness of the aquifer often yield 100 to $500 \mathrm{gal} / \mathrm{min}$ (Westerfield, 1994).

Withdrawals from the Cockfield aquifer in the study area during 2000 totaled about $9.9 \mathrm{Mgal} / \mathrm{d}$ (Holland, 2004) (fig. 3). Withdrawals from the Cockfield aquifer generally increased from 1975 to 2000, the exception being a decrease in 1985, producing $5.2 \mathrm{Mgal} / \mathrm{d}$ in $1975,7.2 \mathrm{Mgal} / \mathrm{d}$ in $1980,5.0 \mathrm{Mgal} / \mathrm{d}$ in $1985,8.1 \mathrm{Mgal} / \mathrm{d}$ in 1990 , and $9.8 \mathrm{Mgal} / \mathrm{d}$ in 1995 (Halberg, 1977; Holland and Ludwig, 1981; Holland, 1987, 1993, 1999, 2004). Most wells completed in the Cockfield aquifer study area provide small volumes of water for domestic and livestock use. In some locations, the Cockfield aquifer yields volumes large enough to supply industrial and public supply systems.

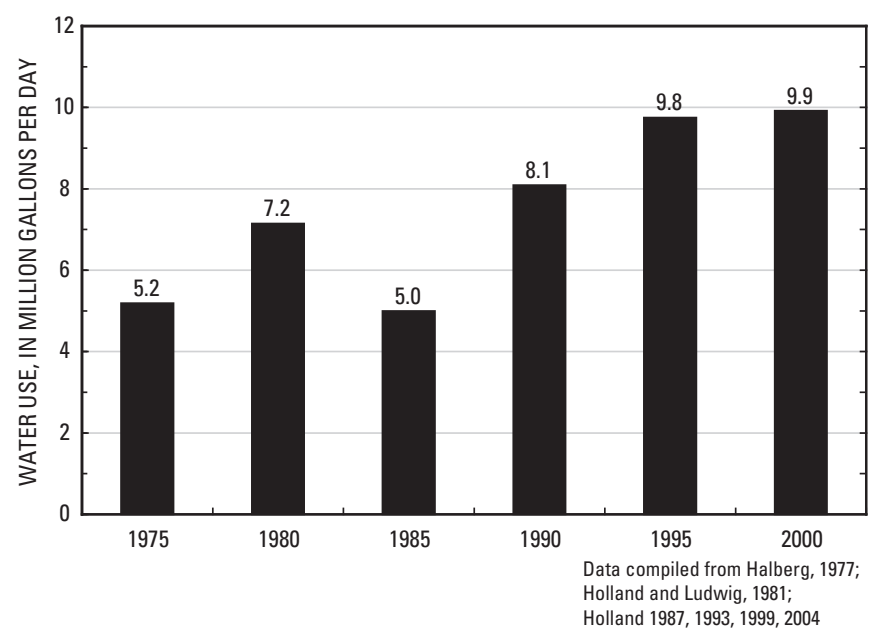

Figure 3. Water use from the Cockfield aquifer, 1975-2000. 
Adjacent to Arkansas, the State of Mississippi pumped about $27 \mathrm{Mgal} / \mathrm{d}$ from the Cockfield aquifer in 1999 (D.E. Burt, U.S. Geological Survey, written commun., 2003). Immediately across the Arkansas/Mississippi State line, the city of Greenville, Mississippi, pumped about $11 \mathrm{Mgal} / \mathrm{d}$ from the Cockfield aquifer in 1999 (D.E. Burt, U.S. Geological Survey, written commun., 2003), or about 11 percent more than all of Arkansas pumped from the Cockfield aquifer in 2000. The large amount of withdrawal from Greenville probably contributes to lower water levels in Arkansas (Ackerman, 1987; Joseph, 1998; Schrader and Joseph, 2000).

\section{Potentiometric Surface}

The potentiometric-surface map shows the altitude of the water surface in 56 tightly cased wells in the Cockfield aquifer (fig. 4) during February and March 2006, in southeastern Arkansas (table 1). The potentiometric surface was constructed by determining the water-level altitude at wells, and constructing contour lines along points of equal water-level altitude. The direction of ground-water flow is perpendicular to the contours in the direction of decreasing water level.
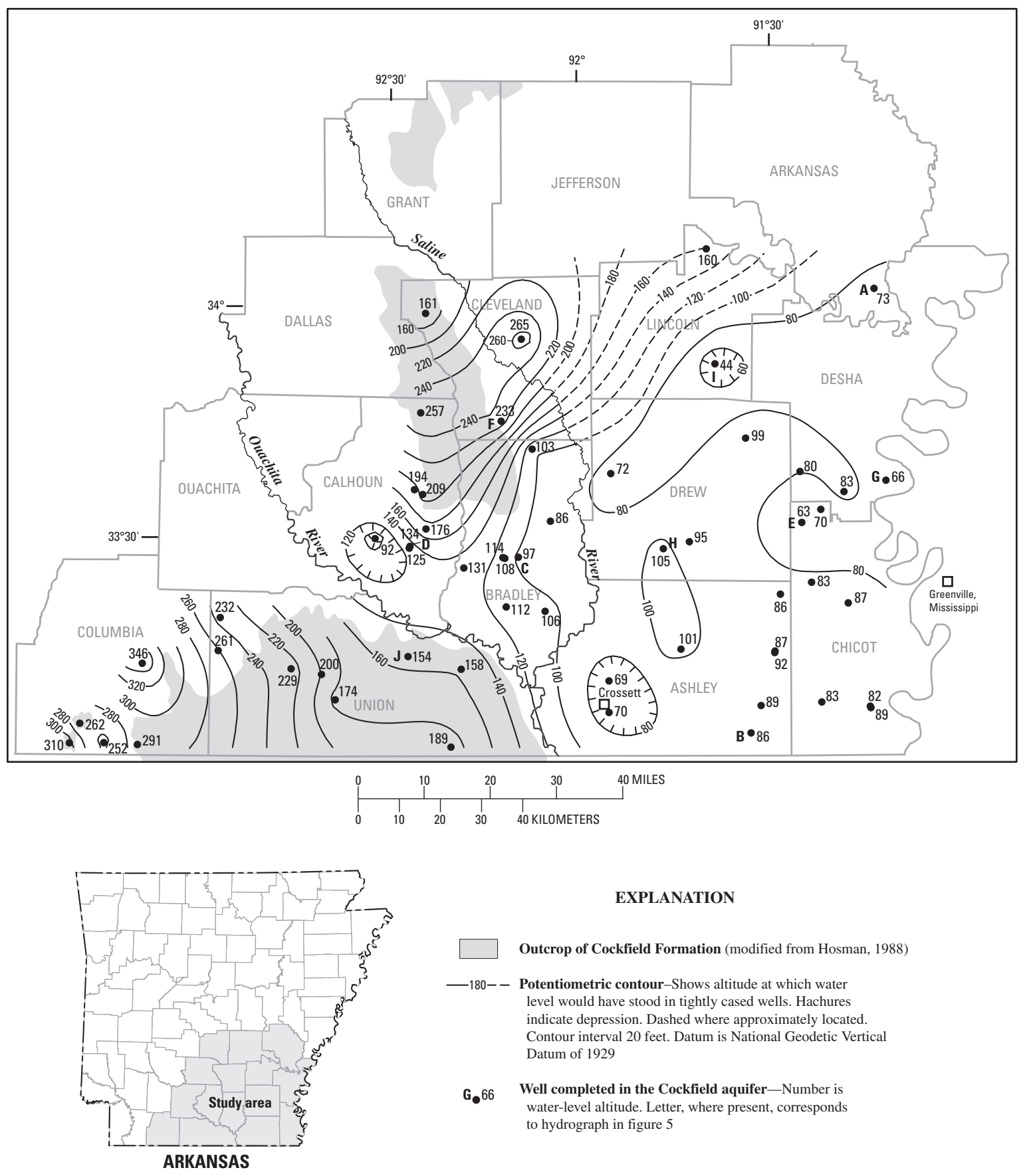

EXPLANATION

Outcrop of Cockfield Formation (modified from Hosman, 1988)

-180- - Potentiometric contour-Shows altitude at which water level would have stood in tightly cased wells. Hachures indicate depression. Dashed where approximately located. Contour interval 20 feet. Datum is National Geodetic Vertical Datum of 1929

G.66 Well completed in the Cockfield aquifer-Number is water-level altitude. Letter, where present, corresponds to hydrograph in figure 5

Figure 4. Potentiometric surface of the Cockfield aquifer in southeastern Arkansas, 2006. 
Table 1. Water-level data collected from wells completed in the Cockfield aquifer in southeastern Arkansas, 2006.

[Horizontal datum is NAD of 1983; NGVD of 1929, National Geodetic Vertical Datum of 1929—a geodetic datum derived from a general adjustment of the first-order level nets of the United States and Canada, formerly called Sea Level Datum of 1929; --, missing data]

\begin{tabular}{|c|c|c|c|c|c|c|c|}
\hline Station Name & $\begin{array}{l}\text { Latitude } \\
\text { (degrees, } \\
\text { minutes, } \\
\text { seconds) }\end{array}$ & $\begin{array}{l}\text { Longitude } \\
\text { (degrees, } \\
\text { minutes, } \\
\text { seconds) }\end{array}$ & $\begin{array}{l}\text { Water-level } \\
\text { altitude } \\
\text { (feet above } \\
\text { NGVD of 1929) }\end{array}$ & $\begin{array}{c}\text { Depth to } \\
\text { water } \\
\text { (feet below } \\
\text { land-surface } \\
\text { datum) }\end{array}$ & $\begin{array}{c}\text { Land-surface } \\
\text { datum } \\
\text { (feet above } \\
\text { NGVD of 1929) }\end{array}$ & $\begin{array}{l}\text { Well depth } \\
\text { (feet) }\end{array}$ & $\begin{array}{c}\text { Date of } \\
\text { measurement }\end{array}$ \\
\hline \multicolumn{8}{|c|}{ Arkansas County } \\
\hline 08S02W04ACA1 & 340139 & 911406 & 73 & 91.62 & 165 & 453 & $3 / 10 / 2006$ \\
\hline \multicolumn{8}{|c|}{ Ashley County } \\
\hline 15S04W26CBC1 & 332144 & 912932 & 86 & 41.88 & 128 & 409 & $3 / 02 / 2006$ \\
\hline 17S04W10BCD2 & 331417 & 913030 & 87 & 38.18 & 125 & 340 & $3 / 02 / 2006$ \\
\hline 17S04W10CBA1 & 331406 & 913033 & 92 & 33.30 & 125 & 360 & $3 / 02 / 2006$ \\
\hline 17S06W07ADA1 & 331442 & 914510 & 101 & 72.85 & 174 & 426 & $3 / 02 / 2006$ \\
\hline 18S04W19DAA2 & 330710 & 913247 & 89 & 26.89 & 116 & 356 & $3 / 02 / 2006$ \\
\hline 18S08W04BBC1 & 331038 & 915627 & 69 & 80.30 & 149 & 314 & $3 / 02 / 2006$ \\
\hline 18S08W29DDD2 & 330630 & 915629 & 70 & 69.80 & 140 & -- & $3 / 02 / 2006$ \\
\hline 19S05W12CAC1 & 330336 & 913425 & 86 & 29.38 & 115 & 320 & $3 / 02 / 2006$ \\
\hline \multicolumn{8}{|c|}{ Bradley County } \\
\hline 12S10W10BCA1 & 334108 & 920807 & 103 & 124.15 & 227 & 425 & $3 / 01 / 2006$ \\
\hline 14S10W01BAD1 & 333139 & 920522 & 86 & 144.55 & 231 & 540 & 3/01/2006 \\
\hline 14S10W31DBA1 & 332658 & 921025 & 97 & 96.47 & 193 & 349 & 3/01/2006 \\
\hline 14S11W35CAB1 & 332656 & 921251 & 114 & 75.89 & 190 & 320 & 3/01/2006 \\
\hline 14S11W35DAC1 & 332650 & 921233 & 108 & 65.68 & 174 & 345 & 3/01/2006 \\
\hline 15S12W11CAB1 & 332536 & 921858 & 131 & 23.94 & 155 & 225 & 3/01/2006 \\
\hline 16S10W11DCB1 & 331951 & 920619 & 106 & 45.51 & 152 & 152 & 3/02/2006 \\
\hline 16S11W11ACA1 & 332027 & 921223 & 112 & 29.36 & 141 & 140 & $3 / 02 / 2006$ \\
\hline \multicolumn{8}{|c|}{ Calhoun County } \\
\hline 11S13W15BBC1 & 334560 & 922534 & 257 & 53.18 & 310 & 70 & $3 / 01 / 2006$ \\
\hline 13S13W09CBD1 & 333555 & 922638 & 194 & 38.03 & 232 & 147 & 3/01/2006 \\
\hline 13S13W15DBA1 & 333517 & 922520 & 209 & 23.40 & 232 & 122 & 3/01/2006 \\
\hline 14S13W11CAC1 & 333045 & 922451 & 176 & 28.55 & 205 & 105 & 3/01/2006 \\
\hline 14S13W29ADA1 & 332829 & 922722 & 134 & 26.02 & 160 & 81 & $3 / 01 / 2006$ \\
\hline 14S13W29DAC1 & 332815 & 922729 & 125 & 14.24 & 139 & -- & 3/01/2006 \\
\hline 14S14W21ACB1 & 332931 & 923249 & 92 & 40.27 & 132 & 160 & 3/01/2006 \\
\hline
\end{tabular}


Table 1. Water-level data collected from wells completed in the Cockfield aquifer in southeastern Arkansas, 2006.—Continued

[Horizontal datum is NAD of 1983; NGVD of 1929, National Geodetic Vertical Datum of 1929—a geodetic datum derived from a general adjustment of the first-order level nets of the United States and Canada, formerly called Sea Level Datum of 1929; --, missing data]

\begin{tabular}{|c|c|c|c|c|c|c|c|}
\hline Station Name & $\begin{array}{l}\text { Latitude } \\
\text { (degrees, } \\
\text { minutes, } \\
\text { seconds) } \\
\end{array}$ & $\begin{array}{c}\text { Longitude } \\
\text { (degrees, } \\
\text { minutes, } \\
\text { seconds) } \\
\end{array}$ & $\begin{array}{c}\text { Water-level } \\
\text { altitude } \\
\text { (feet above } \\
\text { NGVD of 1929) }\end{array}$ & $\begin{array}{c}\text { Depth to } \\
\text { water } \\
\text { (feet below } \\
\text { land-surface } \\
\text { datum) }\end{array}$ & $\begin{array}{c}\text { Land-surface } \\
\text { datum } \\
\text { (feet above } \\
\text { NGVD of 1929) }\end{array}$ & $\begin{array}{l}\text { Well depth } \\
\text { (feet) }\end{array}$ & $\begin{array}{c}\text { Date of } \\
\text { measurement }\end{array}$ \\
\hline \multicolumn{8}{|c|}{ Chicot County } \\
\hline 13S03W26BBB1 & 333247 & 912301 & 70 & 69.34 & 139 & 422 & $3 / 02 / 2006$ \\
\hline 14S03W05BBA1 & 333106 & 912602 & 63 & 75.69 & 139 & 510 & $3 / 02 / 2006$ \\
\hline 15S03W21ABA1 & 332314 & 912438 & 83 & 38.91 & 122 & 400 & $3 / 02 / 2006$ \\
\hline 16S02W04BAC1 & 332027 & 911857 & 87 & 38.07 & 125 & 330 & $3 / 02 / 2006$ \\
\hline 18S02W24CDB1 & 330652 & 911547 & 82 & 47.07 & 129 & 364 & $3 / 02 / 2006$ \\
\hline 18S02W25ABB3 & 330640 & 911541 & 89 & 46.27 & 135 & 332 & $3 / 02 / 2006$ \\
\hline 18S03W14CCC1 & 330731 & 912319 & 83 & 14.86 & 98 & 320 & $3 / 02 / 2006$ \\
\hline \multicolumn{8}{|c|}{ Cleveland County } \\
\hline 08S13W34BDA1 & 335902 & 922444 & 161 & 87.02 & 248 & 181 & $3 / 06 / 2006$ \\
\hline 09S10W17CDD1 & 335534 & 920942 & 265 & 4.73 & 270 & 361 & 3/06/2006 \\
\hline 11S11W23BBD1 & 334449 & 921258 & 233 & 42.03 & 275 & 148 & $3 / 06 / 2006$ \\
\hline \multicolumn{8}{|c|}{ Columbia County } \\
\hline 17S20W35BBD1 & 331313 & 930914 & 346 & 14.91 & 361 & -- & $2 / 28 / 2006$ \\
\hline 19S20W34ADC1 & 330233 & 930958 & 291 & 22.37 & 313 & 39.8 & $2 / 28 / 2006$ \\
\hline 19S21W17CBB1 & 330520 & 931857 & 262 & 44.12 & 306 & 54.8 & $2 / 28 / 2006$ \\
\hline 19S21W35ADC1 & 330247 & 931513 & 252 & 3.54 & 256 & 30.1 & $2 / 28 / 2006$ \\
\hline 19S22W36DBB1 & 330245 & 932034 & 310 & 41.15 & 351 & 68.6 & $2 / 28 / 2006$ \\
\hline \multicolumn{8}{|c|}{ Desha County } \\
\hline 12S01W32DCA1 & 333628 & 911245 & 66 & 69.87 & 136 & 495 & $3 / 06 / 2006$ \\
\hline 12S03W30ADC1 & 333747 & 912611 & 80 & 72.99 & 153 & 280 & $3 / 06 / 2006$ \\
\hline 13S02W08CAA1 & 333504 & 911921 & 83 & 64.48 & 147 & 515 & $3 / 06 / 2006$ \\
\hline \multicolumn{8}{|c|}{ Drew County } \\
\hline 11S05W35DDB1 & 334216 & 913438 & 99 & 81.08 & 180 & 500 & $3 / 03 / 2006$ \\
\hline 12S08W33AAB1 & 333750 & 915551 & 72 & 101.02 & 173 & 543 & $3 / 03 / 2006$ \\
\hline 14S06W21BDC1 & 332846 & 914339 & 95 & 120.62 & 216 & -- & $3 / 03 / 2006$ \\
\hline 14S07W26BAB1 & 332754 & 914744 & 105 & 125.04 & 230 & 440 & $3 / 03 / 2006$ \\
\hline
\end{tabular}


Table 1. Water-level data collected from wells completed in the Cockfield aquifer in southeastern Arkansas, 2006.-Continued

[Horizontal datum is NAD of 1983; NGVD of 1929, National Geodetic Vertical Datum of 1929—a geodetic datum derived from a general adjustment of the first-order level nets of the United States and Canada, formerly called Sea Level Datum of 1929; --, missing data]

\begin{tabular}{|c|c|c|c|c|c|c|c|}
\hline Station Name & $\begin{array}{l}\text { Latitude } \\
\text { (degrees, } \\
\text { minutes, } \\
\text { seconds) }\end{array}$ & $\begin{array}{l}\text { Longitude } \\
\text { (degrees, } \\
\text { minutes, } \\
\text { seconds) }\end{array}$ & $\begin{array}{l}\text { Water-level } \\
\text { altitude } \\
\text { (feet above } \\
\text { NGVD of 1929) }\end{array}$ & $\begin{array}{c}\text { Depth to } \\
\text { water } \\
\text { (feet below } \\
\text { land-surface } \\
\text { datum) }\end{array}$ & $\begin{array}{l}\text { Land-surface } \\
\text { datum } \\
\text { (feet above } \\
\text { NGVD of 1929) }\end{array}$ & $\begin{array}{l}\text { Well depth } \\
\text { (feet) }\end{array}$ & $\begin{array}{c}\text { Date of } \\
\text { measurement }\end{array}$ \\
\hline \multicolumn{8}{|c|}{ Lincoln County } \\
\hline 07S06W14BBC1 & 340709 & 914026 & 160 & 22.22 & 182 & 483 & $3 / 06 / 2006$ \\
\hline 10S05W06CAC1 & 335204 & 913918 & 44 & 126.30 & 170 & 550 & $3 / 06 / 2006$ \\
\hline \multicolumn{8}{|c|}{ Union County } \\
\hline 16S18W22DCD1 & 331913 & 925704 & 232 & 14.71 & 247 & 36 & $2 / 28 / 2006$ \\
\hline 17S12W27DCA1 & 331219 & 921929 & 158 & 11.91 & 170 & 24 & $3 / 01 / 2006$ \\
\hline 17S13W17DDC1 & 331402 & 922746 & 154 & 38.67 & 193 & 156 & 2/28/2006 \\
\hline 17S15W31DCA2 & 331144 & 924116 & 200 & 52.99 & 253 & 110 & $3 / 01 / 2006$ \\
\hline 17S16W33BBA2 & 331229 & 924601 & 229 & 25.54 & 255 & 31 & $2 / 28 / 2006$ \\
\hline 17S18W15CDA1 & 331453 & 925723 & 261 & 28.82 & 290 & 35 & $2 / 28 / 2006$ \\
\hline 18S15W21DAC1 & 330824 & 923909 & 174 & 26.13 & 200 & 40 & 3/01/2006 \\
\hline 19S12W28CBA1 & 330207 & 922109 & 189 & 10.73 & 200 & 25 & $3 / 01 / 2006$ \\
\hline
\end{tabular}

The regional direction of ground-water flow generally is towards the east and southeast, away from the outcrop, except in areas of intense ground-water withdrawals, such as western Drew County, southeastern Lincoln County, southwestern Calhoun County, and near Crossett in Ashley County (Schrader and Joseph, 2000). There are three cones of depression indicated by relatively low water-level altitudes in southeastern Lincoln County, southwestern Calhoun County, and near Crossett in Ashley County. The cones of depression in southeastern Lincoln and southwestern Calhoun Counties were not evident in the 2003 potentiometric-surface map (Yeatts, 2004) but more data or different wells were available for 2006. Some local ground-water flow in the outcrop area is toward rivers that have eroded into the Cockfield Formation and deposited alluvium in southern Bradley and Calhoun Counties (Ouachita River), and in north Dallas County (Saline River). The lowest water-level altitude measured was $44 \mathrm{ft}$ in Lincoln County; the highest water-level altitude measured was $346 \mathrm{ft}$ in Columbia County at the outcrop area.

\section{Water-Level Trends}

Water-level trends in the Cockfield aquifer are illustrated by plotting the water levels in hydrographs, and evaluating the change in water level over a period of time. Hydrographs from 41 wells with historical water levels from 1986 to 2006 were evaluated using linear regression to calculate the annual rise or decline, in feet per year, for each well and grouped by county (table 2). Table 2 shows the number of wells with a minimum 20 years of record, the range of annual rise or decline, and the mean and median annual rise or decline by county. Arkansas, Desha, Drew, and Lincoln Counties only had one well with a minimum 20 years of record. Calhoun and Cleveland Counties have mean annual rises from 0.01 to $0.07 \mathrm{ft} / \mathrm{yr}$. Arkansas, Ashley, Bradley, Chicot, Columbia, Drew, Lincoln, and Union Counties have mean annual declines from 0.04 to $0.55 \mathrm{ft} / \mathrm{yr}$. Desha County has a mean annual decline of about $1.35 \mathrm{ft} / \mathrm{yr}$. Historical water-level data from ten wells (wells A-J, fig. 4) in the Cockfield aquifer were plotted to illustrate the water-level trend in selected areas of southeastern Arkansas (fig. 5). The hydrographs were selected with an annual rise or decline near the mean annual rise or decline for the respective county. 
Table 2. Range, mean, and median of annual rise/decline in water level by county for wells in the aquifer, 1986-2006.

[Annual rise or decline in water level for each well is calculated using linear regression]

\begin{tabular}{|c|c|c|c|c|c|}
\hline County & $\begin{array}{c}\text { Number of } \\
\text { wells }\end{array}$ & $\begin{array}{l}\text { Range or value } \\
\text { of annual } \\
\text { rise/decline (-) } \\
\text { in water level } \\
\text { (feet/year) }\end{array}$ & $\begin{array}{c}\text { Mean annual } \\
\text { rise/decline (-) } \\
\text { in water level } \\
\text { (feet/year) }\end{array}$ & $\begin{array}{c}\text { Median annual } \\
\text { rise/decline (-) } \\
\text { in water level } \\
\text { (feet/year) }\end{array}$ & $\begin{array}{c}\text { Range of } R^{2} \\
\text { values for } \\
\text { trend line }\end{array}$ \\
\hline Arkansas $^{1}$ & 1 & -0.55 & -0.55 & -0.55 & 0.33 \\
\hline Ashley & 6 & -0.55 to 0.00 & -0.33 & -0.33 & 0.01 to 0.87 \\
\hline Bradley & 5 & -0.55 to 0.22 & -0.24 & -0.29 & 0.07 to 0.94 \\
\hline Calhoun & 5 & -0.22 to 0.18 & 0.01 & 0.15 & 0.01 to 0.76 \\
\hline Chicot & 5 & -0.84 to -0.11 & -0.42 & -0.29 & 0.14 to 0.84 \\
\hline Cleveland & 2 & -0.11 to 0.26 & 0.07 & 0.07 & 0.42 to 0.47 \\
\hline Columbia & 5 & -0.40 to 0.29 & -0.04 & -0.01 & 0.01 to 0.49 \\
\hline Desha $^{1}$ & 1 & -1.35 & -1.35 & -1.35 & 0.94 \\
\hline Drew $^{1}$ & 1 & -0.47 & -0.47 & -0.47 & 0.97 \\
\hline $\operatorname{Lincoln}^{1}$ & 1 & -0.33 & -0.33 & -0.33 & 0.10 \\
\hline Union & 9 & -0.80 to 0.55 & -0.13 & -0.15 & 0.06 to 0.92 \\
\hline
\end{tabular}

${ }^{1}$ County produced one hydrograph of 20 years or more. 


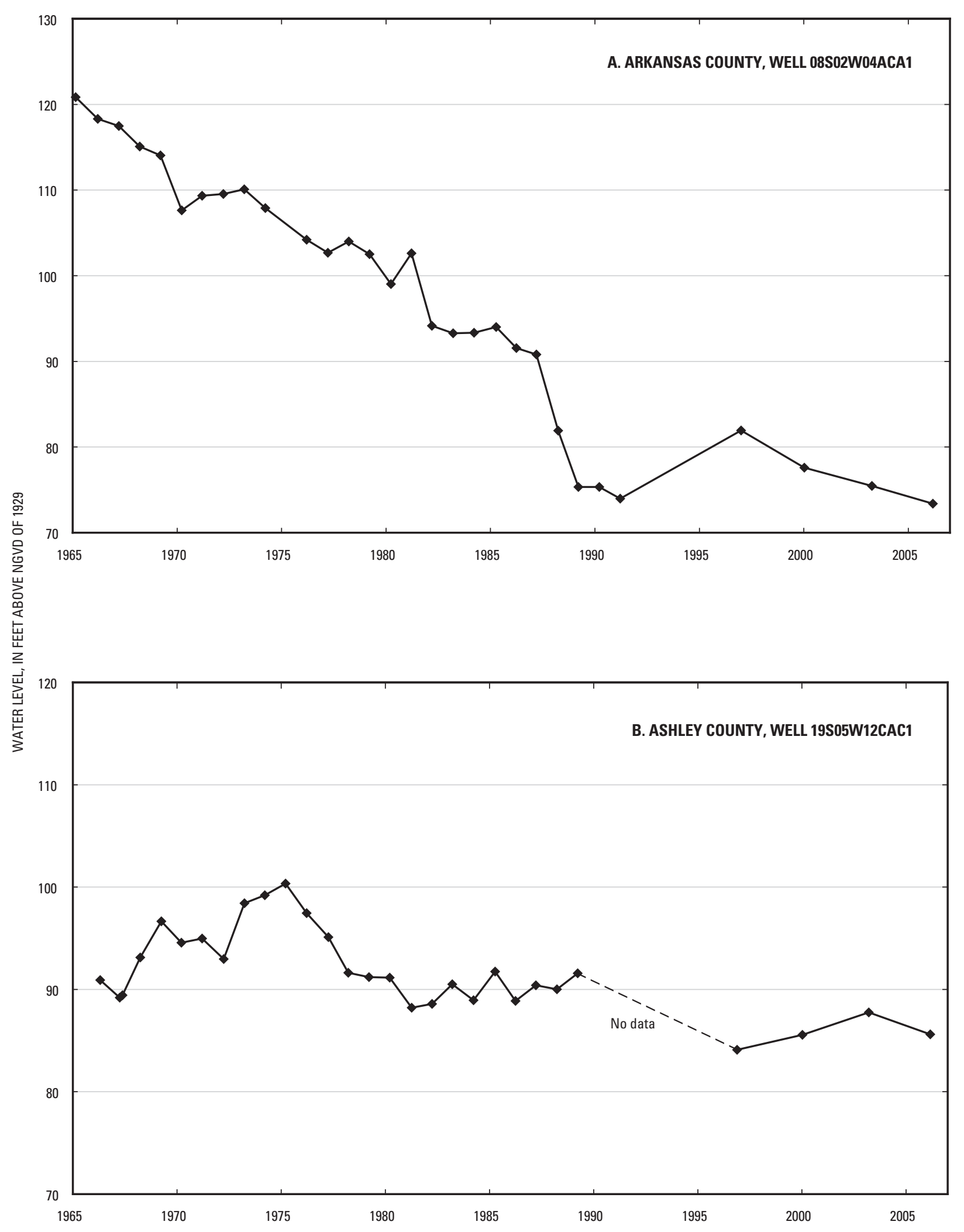

Figure 5. Water-level hydrographs for selected wells completed in the Cockfield aquifer in southeastern Arkansas. 


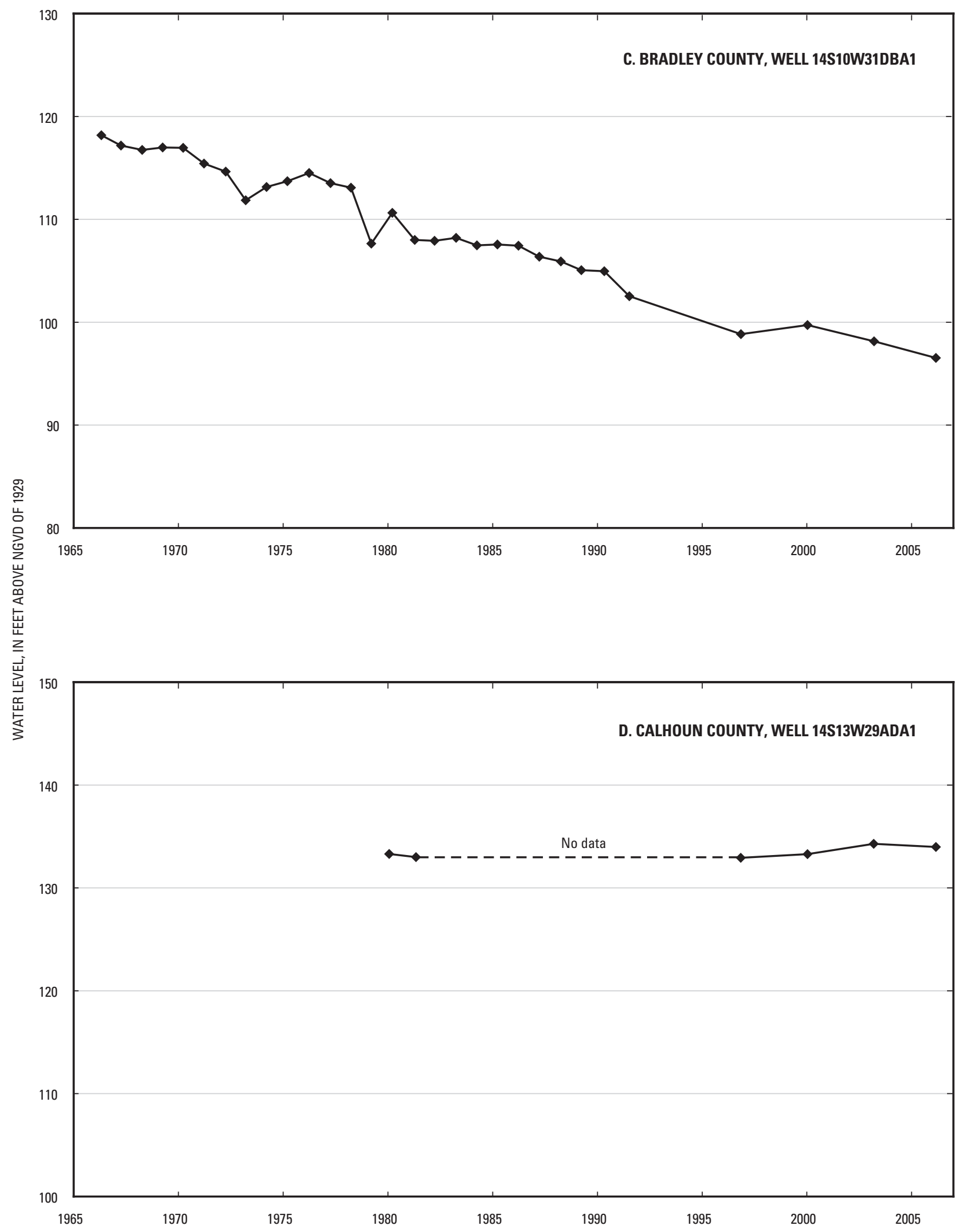

Figure 5. Water-level hydrographs for selected wells completed in the Cockfield aquifer in southeastern Arkansas.—Continued 


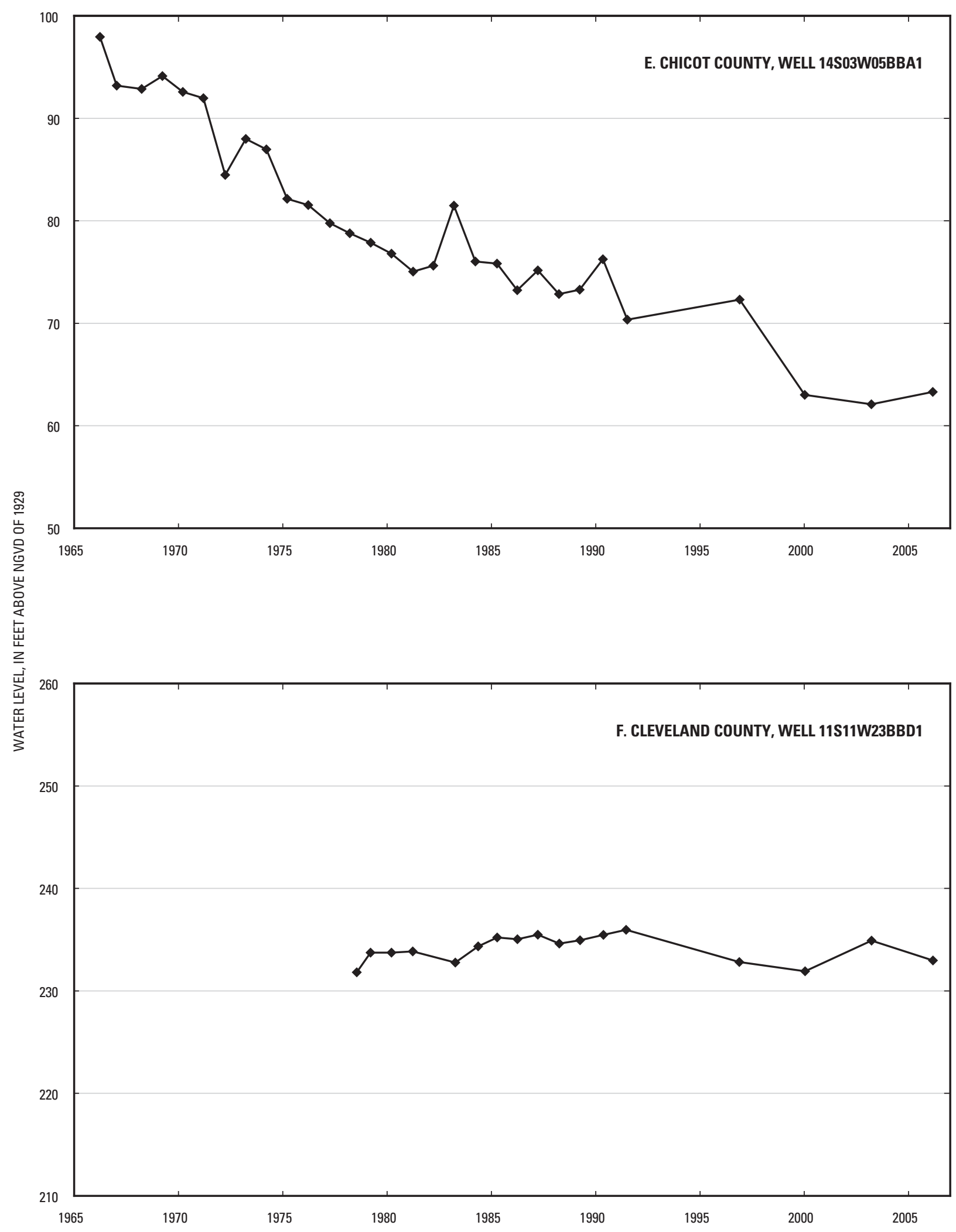

Figure 5. Water-level hydrographs for selected wells completed in the Cockfield aquifer in southeastern Arkansas.-Continued 


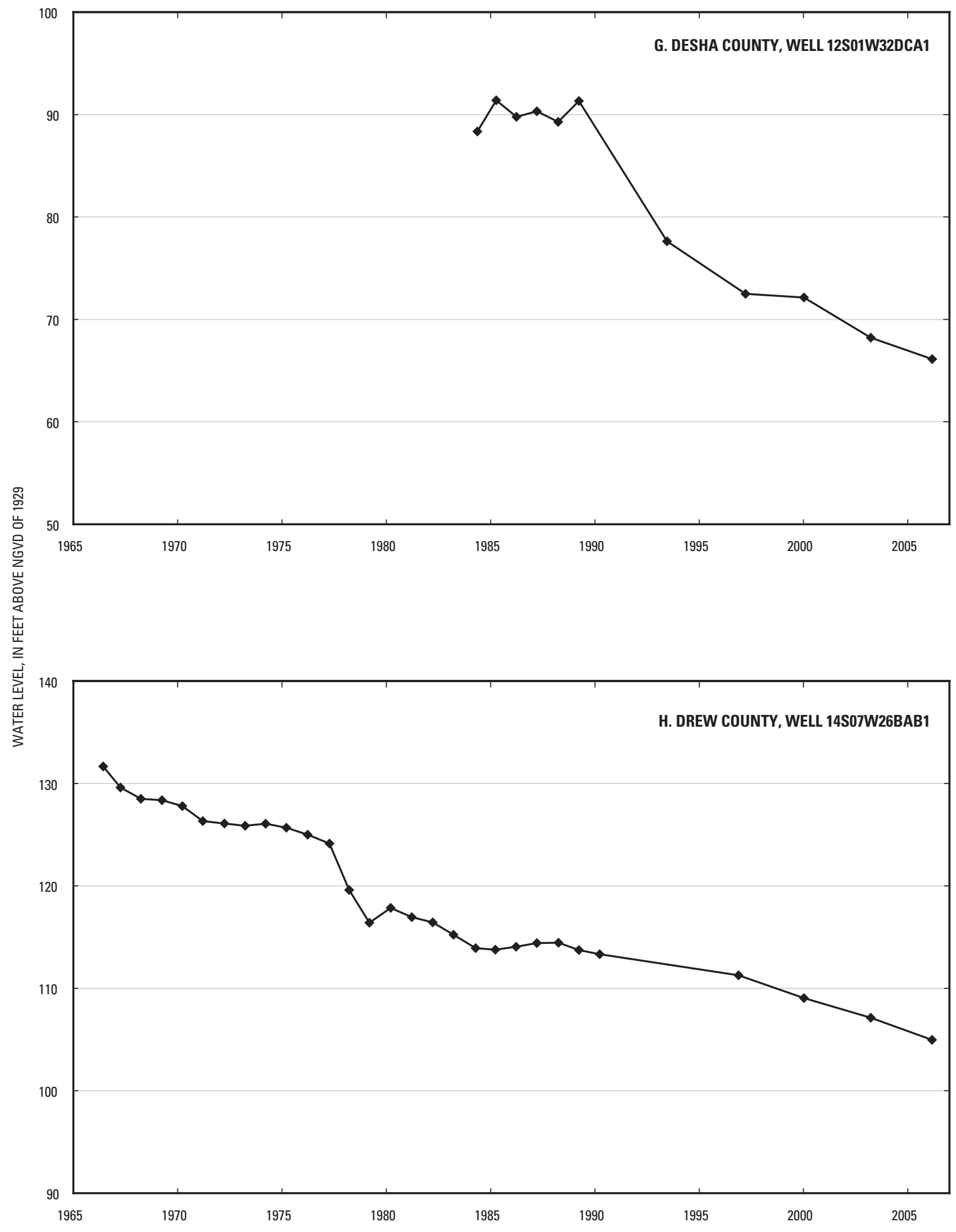

Figure 5. Water-level hydrographs for selected wells completed in the Cockfield aquifer in southeastern Arkansas.-Continued 


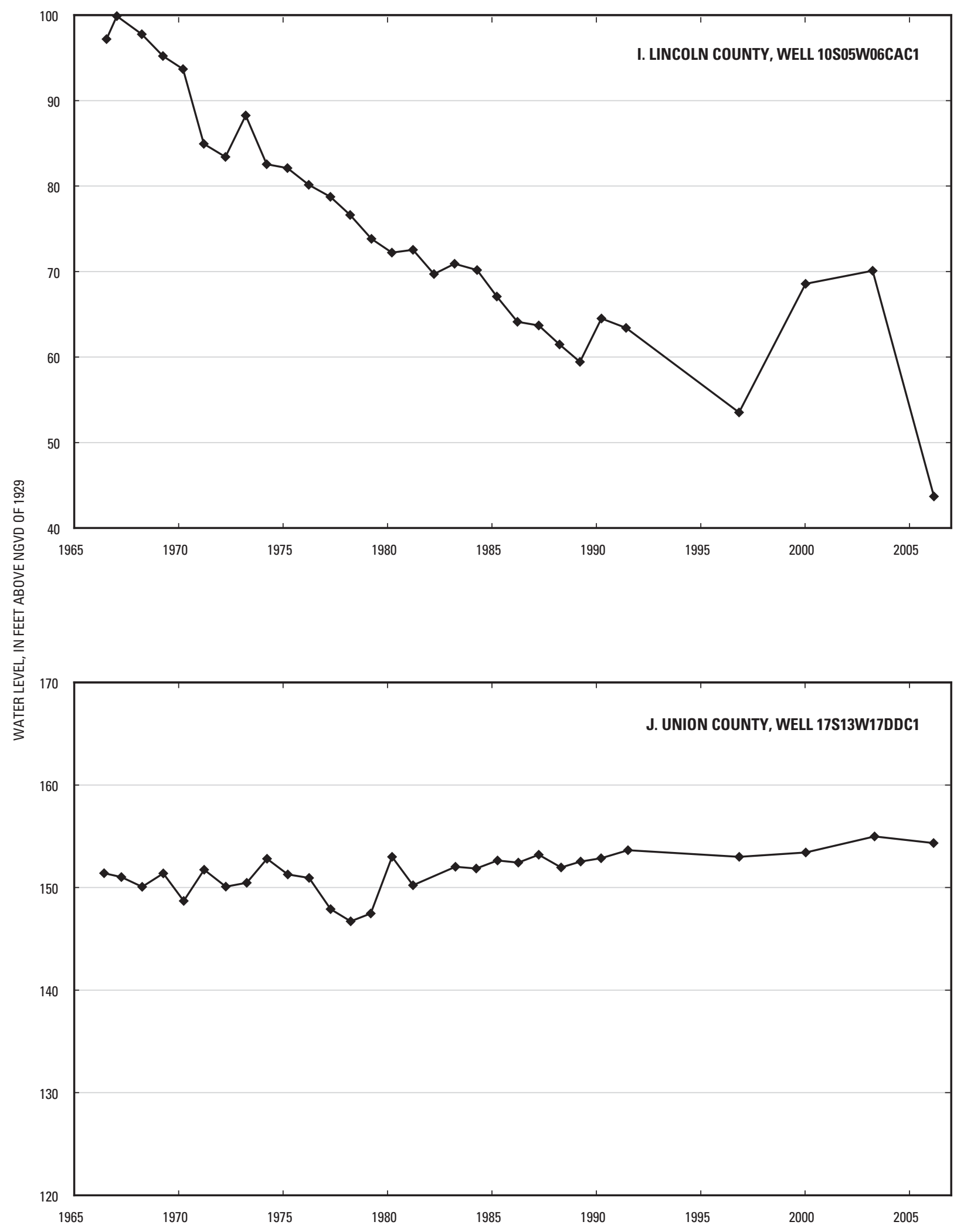

Figure 5. Water-level hydrographs for selected wells completed in the Cockfield aquifer in southeastern Arkansas.—Continued 


\section{Wilcox Group}

\section{Hydrogeologic Setting}

The Wilcox Group of Eocene and Paleocene age is located throughout most of southern and eastern Arkansas. The Wilcox aquifer comprises water-yielding strata within the Wilcox Group in two study areas in the southwestern and northeastern portions of Arkansas. The Wilcox aquifer in central Arkansas is not extensively used, and water-level data are insufficient to determine the potentiometric surface.

The Wilcox Group in the southwestern study area consists of interbedded layers of clay, sandy clay, sand, and lignite. Formations in the southwestern study area are undifferentiated. Sand beds generally are thin and are not continuous over large areas. In most of the southwestern study area, the Wilcox Group overlies the Midway Group and is overlain by terrace deposits and alluvium of Quaternary age or crops out in discontinuous bands that are 1 to 3 miles wide. The Wilcox Group becomes progressively thicker downslope from the outcrop, ranging in thickness from a few feet in the outcrop to about $750 \mathrm{ft}$ in northeastern Bradley County (Albin, 1964).

Recharge to the southwestern study area occurs by infiltration of rainfall in the outcrop areas and by inflow from overlying terrace and alluvial deposits; discharge flows to streams in the outcrop, to overlying formations where the aquifer is confined, and to wells (Westerfield, 1994). Well depths are shallow and well yields range from 10 to $100 \mathrm{gal} /$ min (Schrader and Joseph, 2000).

The Wilcox Group in most of the northeastern study area consists of thin interbedded layers of lignitic sand and clays. The Wilcox Group outcrops at or near Crowleys Ridge in Clay, Greene, and Craighead Counties (Broom and Lyford, 1981). East of Crowleys Ridge, the middle to lower part of the Wilcox Group contains a sand bed of $200 \mathrm{ft}$ or more in thickness (Petersen and others, 1985) referred to as the "1,400-foot sand" (Ryling, 1960; Plebuch, 1961) or the "lower Wilcox aquifer" (Hosman and others, 1968). The Wilcox aquifer in the northeastern study area is confined above by a clay bed of the Wilcox Group and underlain below by a clay bed of the Wilcox Group or the Midway Group.

Recharge to the northeastern study area occurs by infiltration of rainfall in the outcrop areas along the western side of Crowleys Ridge; discharge occurs by wells and by flow beneath the Mississippi River into Mississippi (Westerfield, 1994). Well depths range from $157 \mathrm{ft}$ on Crowleys Ridge in Clay County to $1,885 \mathrm{ft}$ in Lee County. Well yields range from 100 to $2,000 \mathrm{gal} / \mathrm{min}$ (Schrader and Joseph, 2000).

Withdrawals from the Wilcox aquifer in the study areas totaled about 22.2 Mgal/d during 2000, most of which came from the northeastern study area (Holland, 2004) (fig. 6). Withdrawals from the Wilcox aquifer generally increased from 1975 to 1995 , the exception being a decrease in 1985, producing 24.3 Mgal/d in 1975, 25.7 Mgal/d in 1980, 21.0 Mgal/d in
$1985,30.9 \mathrm{Mgal} / \mathrm{d}$ in 1990, and $41.0 \mathrm{Mgal} / \mathrm{d}$ in 1995 (Halberg, 1977; Holland and Ludwig, 1981; Holland, 1987, 1993, 1999). In the southern study area, the primary use of water from the aquifer was for domestic supplies, usually from wells on or near the outcrop areas. In the northeastern study area, the primary use of water from the aquifer was for public supplies, but the aquifer is also a source of water for some commercial, domestic, and industrial users.

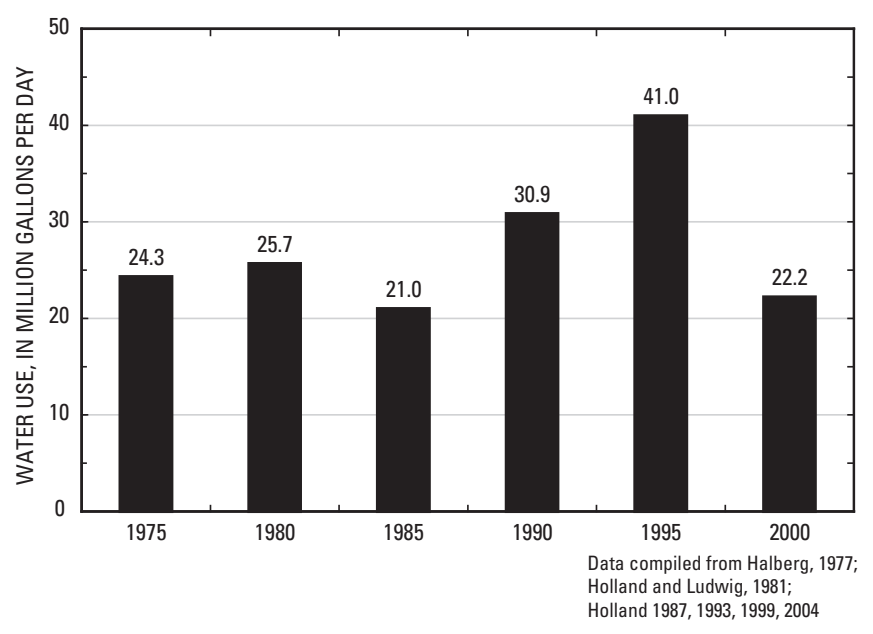

Figure 6. Water use from the Wilcox aquifer, 1975-2000.

\section{Potentiometric Surface}

The potentiometric-surface maps show the altitude of the water surface in tightly cased wells screened in the Wilcox aquifer (figs. 7 and 8). The maps are based upon water-level data collected from 59 wells during February and March 2006, 16 wells in the Wilcox aquifer southwestern study area and at 43 wells in the Wilcox aquifer northeastern study area (tables 3 and 4). The potentiometric surface was constructed by determining the water-level altitude in wells and constructing contour lines along points of equal water-level values. The direction of ground-water flow is perpendicular to the contours in the direction of decreasing water level.

The direction of ground-water flow in the southwestern study area generally is south and east, except in Clark County where flow is towards the Ouachita River, which has eroded into the Wilcox Group and deposited alluvium. The lowest water-level altitude measured in southwestern Arkansas was $147 \mathrm{ft}$ near the Ouachita River in Clark County; the highest water-level altitude measured was $397 \mathrm{ft}$ in the outcrop area of Hempstead County. 


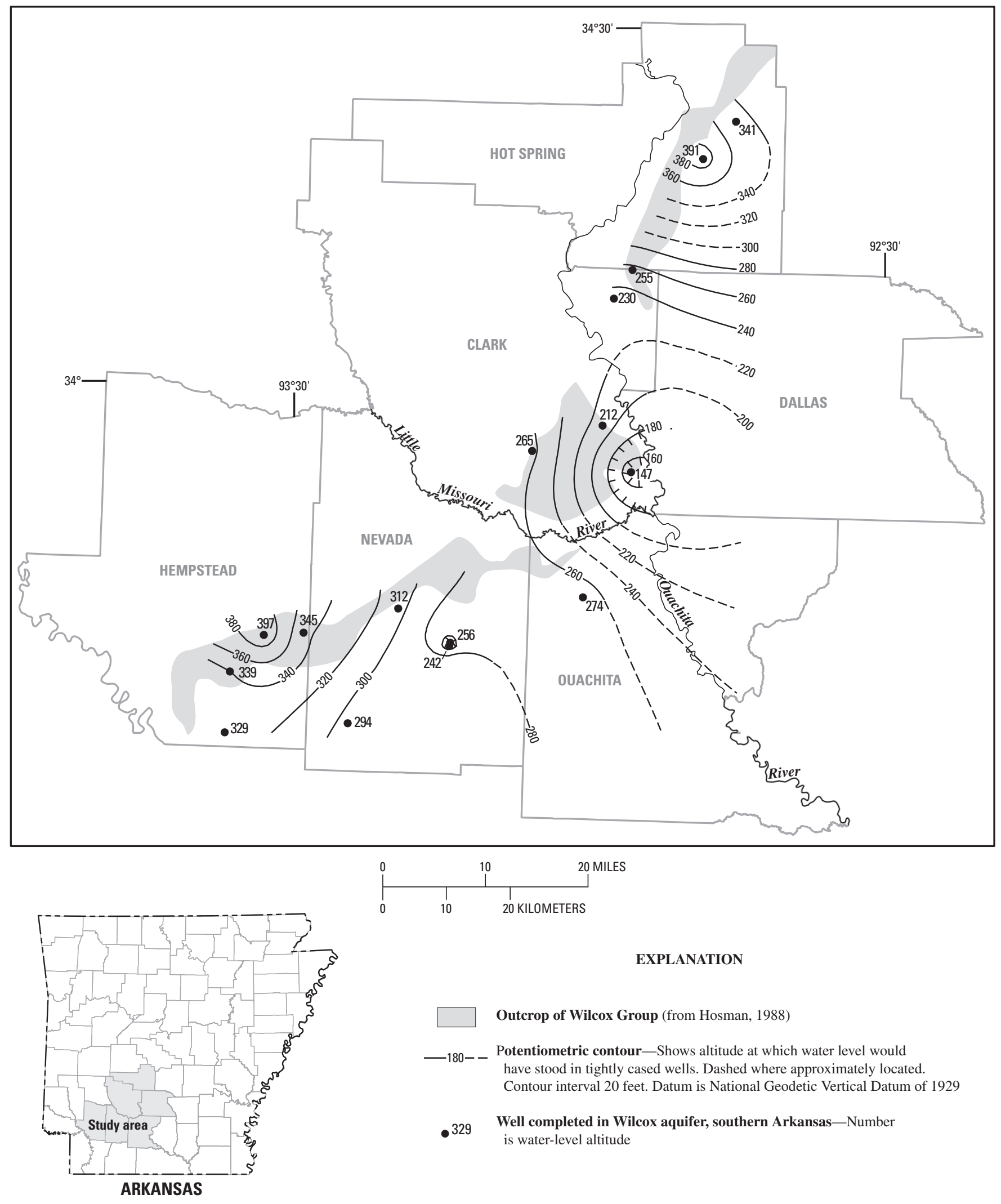

Figure 7. Potentiometric surface of the Wilcox aquifer in southern Arkansas, 2006. 


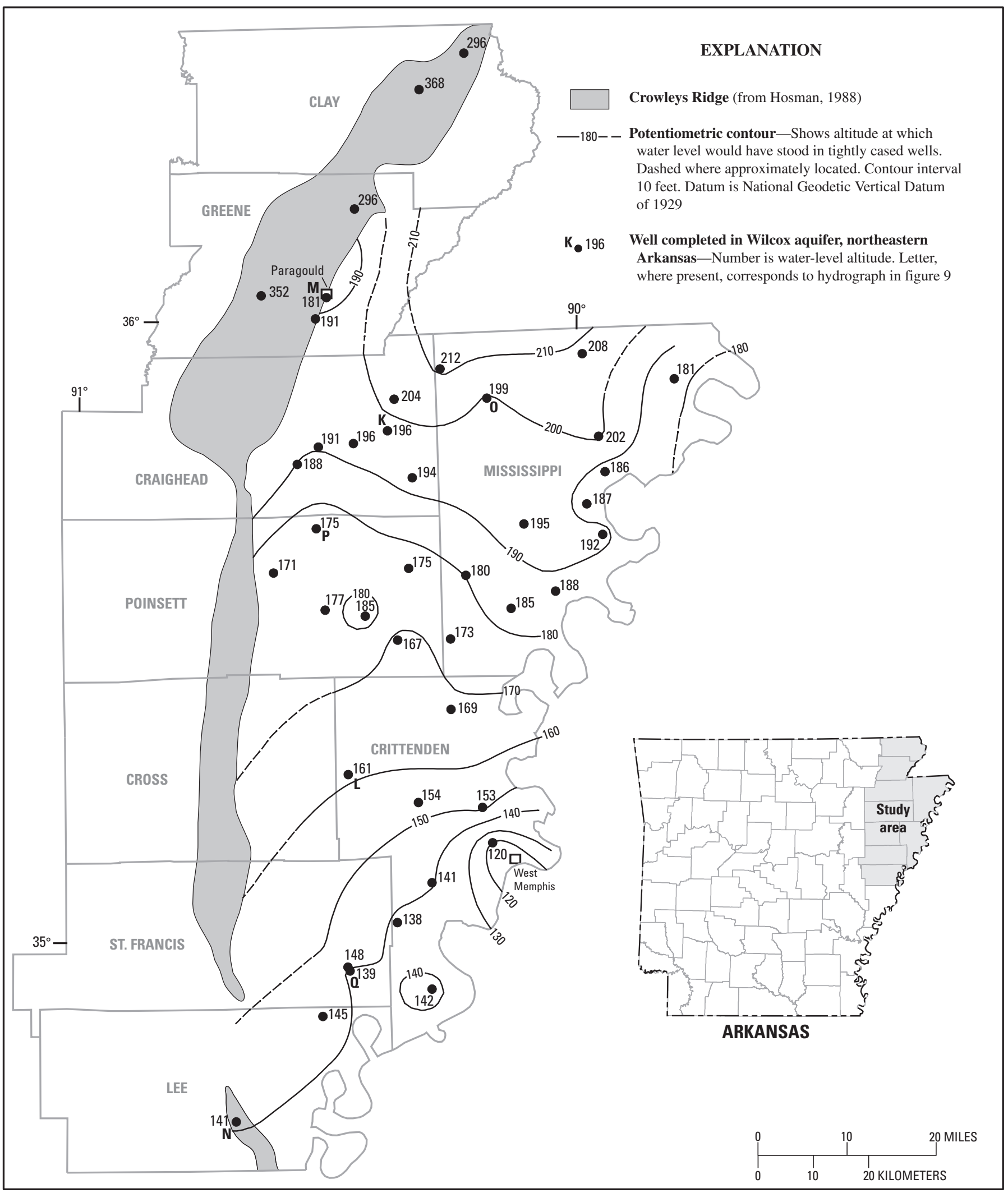

Figure 8. Potentiometric surface of the Wilcox aquifer in northeastern Arkansas, 2006. 
Table 3. Water-level data collected from wells completed in the Wilcox aquifer in southwestern Arkansas, 2006.

[Horizontal datum is NAD is NAD of 1983; NGVD of 1929, National Geodetic Vertical Datum of 1929—a geodetic datum derived from a general adjustment of the first-order level nets of the United States and Canada, formerly called Sea Level Datum of 1929; --, no data]

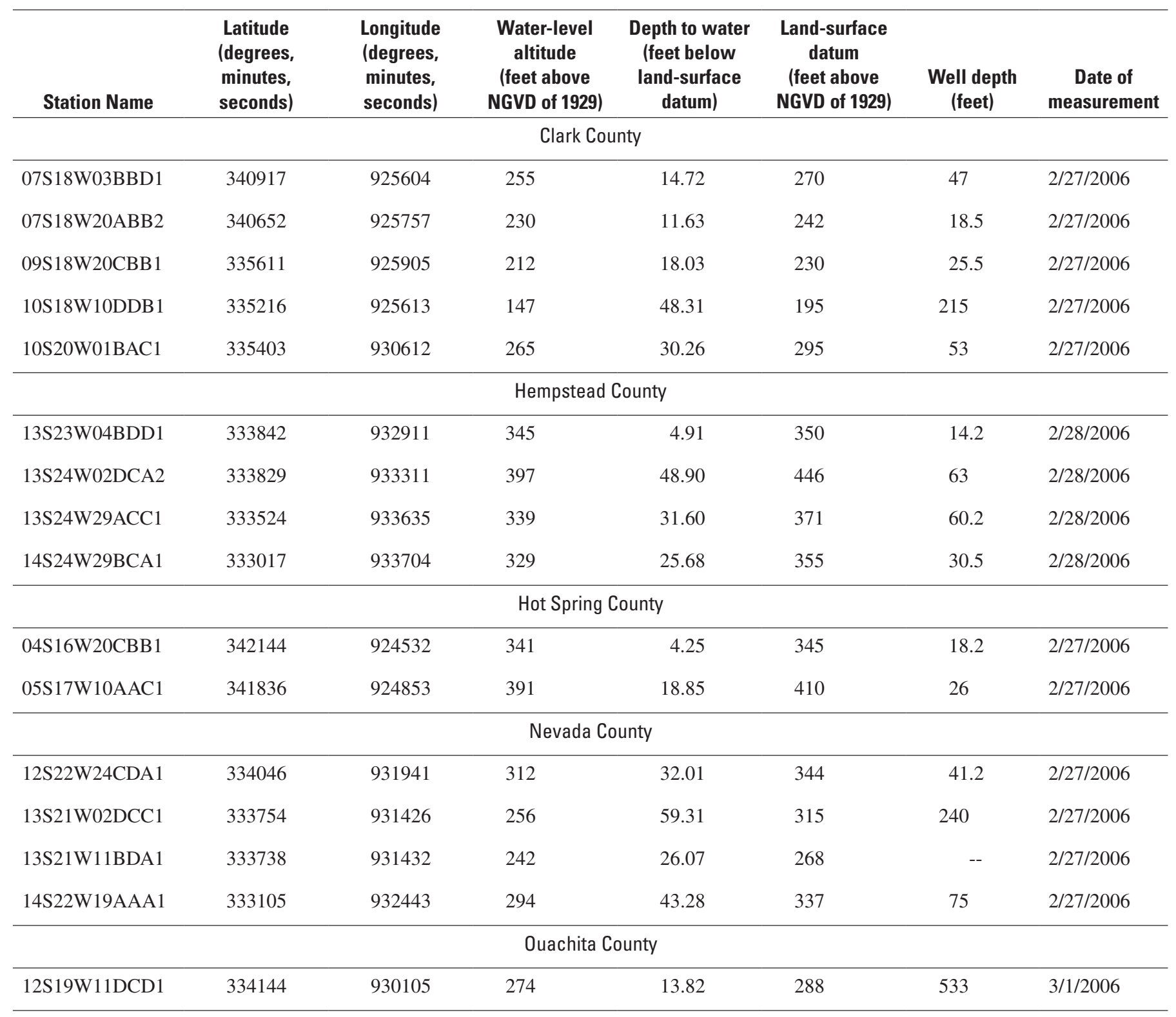


Table 4. Water-level data collected from wells completed in the Wilcox aquifer in northeastern Arkansas, 2006.

[Horizontal datum is NAD is NAD of 1983; NGVD of 1929, National Geodetic Vertical Datum of 1929—a geodetic datum derived from a general adjustment of the first-order level nets of the United States and Canada, formerly called Sea Level Datum of 1929]

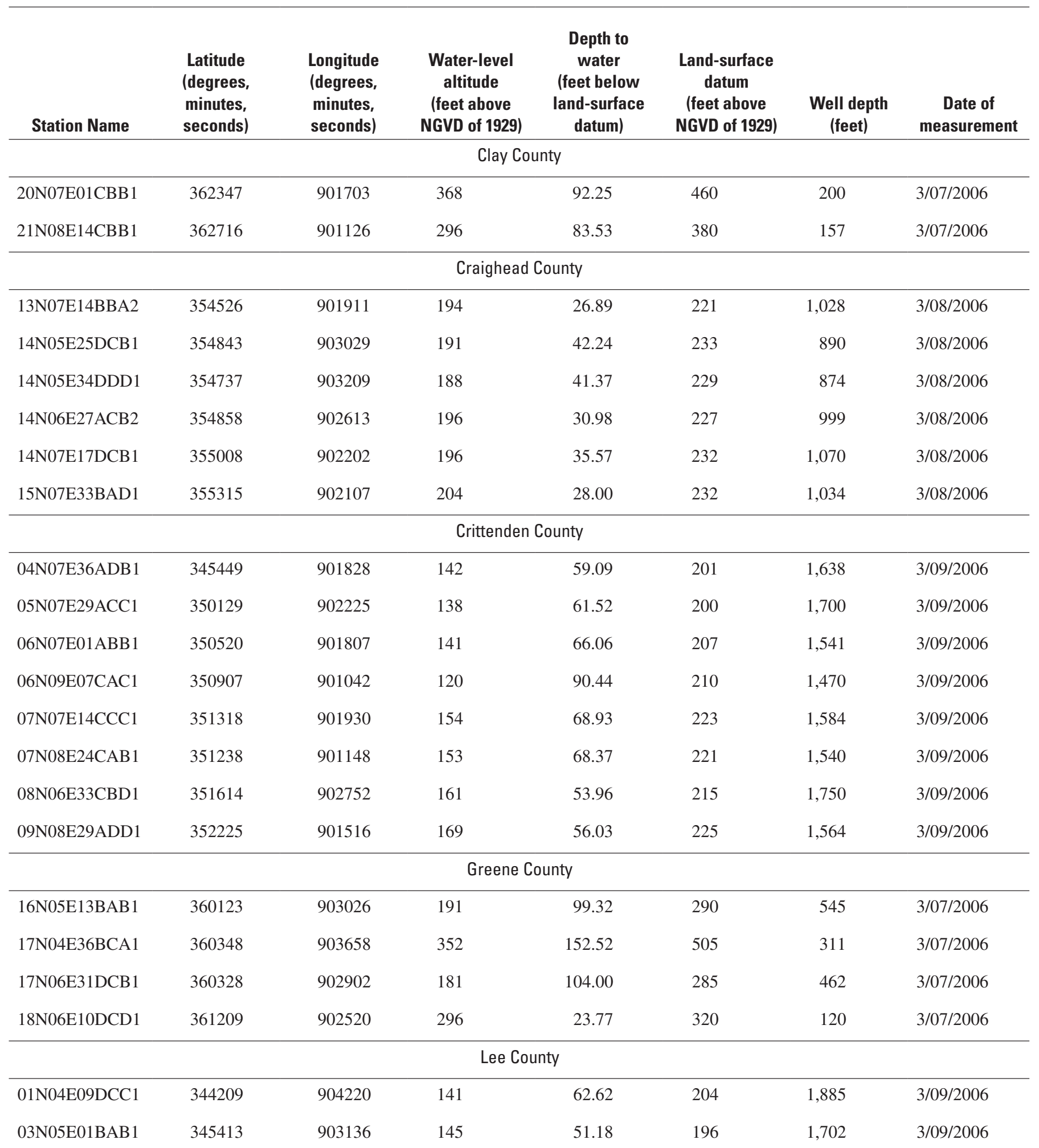


Table 4. Water-level data collected from wells completed in the Wilcox aquifer in northeastern Arkansas, 2006.—Continued

[Horizontal datum is NAD is NAD of 1983; NGVD of 1929, National Geodetic Vertical Datum of 1929—a geodetic datum derived from a general adjustment of the first-order level nets of the United States and Canada, formerly called Sea Level Datum of 1929]

\begin{tabular}{|c|c|c|c|c|c|c|c|}
\hline Station Name & $\begin{array}{c}\text { Latitude } \\
\text { (degrees, } \\
\text { minutes, } \\
\text { seconds) }\end{array}$ & $\begin{array}{c}\text { Longitude } \\
\text { (degrees, } \\
\text { minutes, } \\
\text { seconds) }\end{array}$ & $\begin{array}{l}\text { Water-level } \\
\text { altitude } \\
\text { (feet above } \\
\text { NGVD of 1929) }\end{array}$ & $\begin{array}{c}\text { Depth to } \\
\text { water } \\
\text { (feet below } \\
\text { land-surface } \\
\text { datum) }\end{array}$ & $\begin{array}{l}\text { Land-surface } \\
\text { datum } \\
\text { (feet above } \\
\text { NGVD of 1929) }\end{array}$ & $\begin{array}{l}\text { Well depth } \\
\text { (feet) }\end{array}$ & $\begin{array}{c}\text { Date of } \\
\text { measurement }\end{array}$ \\
\hline \multicolumn{8}{|c|}{ Mississippi County } \\
\hline 10N08E17ADD1 & 352923 & 901505 & 173 & 52.40 & 225 & 1,521 & $3 / 08 / 2006$ \\
\hline 11N08E10AAC2 & 353538 & 901301 & 180 & 40.07 & 220 & 1,380 & $3 / 08 / 2006$ \\
\hline 11N09E33AAB1 & 353214 & 900739 & 185 & 52.29 & 237 & 1,560 & $3 / 08 / 2006$ \\
\hline 11N10E20ADA1 & 353349 & 900213 & 188 & 47.07 & 235 & 1,417 & $3 / 08 / 2006$ \\
\hline 12N09E11DBB1 & 354033 & 900548 & 195 & 35.23 & 230 & 1,452 & $3 / 08 / 2006$ \\
\hline 12N11E17CDD1 & 353917 & 895618 & 192 & 52.79 & 245 & 1,500 & $3 / 08 / 2006$ \\
\hline 13N11E08DDA1 & 354528 & 895547 & 186 & 59.03 & 245 & 1,445 & 3/08/2006 \\
\hline $\begin{array}{c}\text { 13N11E31C- } \\
\text { CCC1 }\end{array}$ & 354221 & 895807 & 187 & 53.51 & 241 & 1,500 & $3 / 08 / 2006$ \\
\hline 14N11E20CCA1 & 354859 & 895626 & 202 & 37.88 & 240 & 1,518 & $3 / 08 / 2006$ \\
\hline 15N08E08DBC3 & 355607 & 901527 & 212 & 25.59 & 238 & 1,060 & $3 / 08 / 2006$ \\
\hline 15N09E31ACD1 & 355306 & 900952 & 199 & 40.69 & 240 & 1,158 & 3/08/2006 \\
\hline 15N10E01ADC1 & 355712 & 895806 & 208 & 39.93 & 248 & 1,350 & 3/08/2006 \\
\hline 15N12E23DBC1 & 355426 & 894701 & 181 & 56.59 & 238 & 1,491 & $3 / 08 / 2006$ \\
\hline \multicolumn{8}{|c|}{ Poinsett County } \\
\hline 10N07E16CBB2 & 352925 & 902129 & 167 & 51.03 & 218 & 1,500 & $3 / 07 / 2006$ \\
\hline 11N05E06CCD1 & 353622 & 903618 & 171 & 42.72 & 214 & 992 & $3 / 07 / 2006$ \\
\hline 11N05E36AAA1 & 353234 & 903009 & 177 & 37.38 & 214 & 1,175 & $3 / 07 / 2006$ \\
\hline 11N06E35CDA3 & 353152 & 902520 & 185 & 30.48 & 215 & 1,301 & $3 / 07 / 2006$ \\
\hline 11N07E03BDD1 & 353629 & 901955 & 175 & 41.03 & 216 & 1,456 & $3 / 07 / 2006$ \\
\hline 12N05E13BBB1 & 354038 & 903059 & 175 & 47.28 & 222 & 1,071 & $3 / 07 / 2006$ \\
\hline \multicolumn{8}{|c|}{ St. Francis County } \\
\hline 04N06E16CCB1 & 345712 & 902830 & 148 & 54.36 & 202 & 1,615 & $3 / 09 / 2006$ \\
\hline 04N06E21BAD2 & 345649 & 902815 & 139 & 61.81 & 201 & 1,740 & $3 / 09 / 2006$ \\
\hline
\end{tabular}


The direction of ground-water flow in the northeastern study area generally is south and east. Larger ground-water withdrawals may have altered the natural direction of flow near the centers of pumping at Paragould and West Memphis (Joseph, 1998). The lowest water-level altitude measured in northeastern Arkansas was $120 \mathrm{ft}$ near West Memphis in Crittenden County; the highest water-level altitude measured was $368 \mathrm{ft}$ on Crowleys Ridge in Clay County. Crowleys Ridge represents an erosional remnant elevated as high as $200 \mathrm{ft}$ above the Mississippi Alluvial Plain. Water levels measured in wells on Crowleys Ridge are higher because of the higher altitude of the Wilcox Group and influence of direct recharge to outcrops and subcrops on the ridge. The water levels on Crowleys Ridge were not included in the construction of the potentiometric surface because of few control points (only four wells).

\section{Water-Level Trends}

Water-level trends in the Wilcox aquifer northeastern study area are illustrated by plotting the water levels in hydrographs, and evaluating the change in water level over a period of time. Hydrographs from 28 wells with historical water levels from 1986 to 2006 were evaluated using linear regression to calculate the annual rise or decline, in feet per year, for each well and grouped by county (table 5). Table 5 shows the number of wells with a minimum of 20 years of record, the range of annual rise or decline, and the mean and median annual rise or decline by county. Lee and St. Francis Counties only had one well with a minimum of 20 years of record. All 28 wells showed an annual decline from 1986 to 2006. Craighead, Greene, Mississippi, and Poinsett Counties have mean annual declines from 0.27 to $1.00 \mathrm{ft} / \mathrm{yr}$. Crittenden, Lee, and St Francis Counties have mean annual decline of from 1.39 to $1.64 \mathrm{ft} / \mathrm{yr}$. Historical water-level data from seven wells (wells K-Q, fig. 8) in the Wilcox aquifer were plotted to illustrate the water-level trend in selected areas of northeastern Arkansas (fig. 9). The hydrographs were selected with an annual rise or decline near the mean annual rise or decline for the respective county. Hydrographs are not shown for wells in the southwestern study area, because the wells did not have 20 years of historical data.

Table 5. Range, mean, and median of annual rise/decline in water level by county for wells in the Wilcox aquifer in the northeastern study area, 1986-2006.

[Annual rise or decline in water level for each well is calculated using linear regression]

\begin{tabular}{lcccc}
\hline \multicolumn{1}{c}{ County } & $\begin{array}{c}\text { Number of } \\
\text { wells }\end{array}$ & $\begin{array}{c}\text { Range or value } \\
\text { of annual } \\
\text { decline (-) in } \\
\text { water level } \\
\text { (feet/year) }\end{array}$ & $\begin{array}{c}\text { Mean annual } \\
\text { decline (-) in } \\
\text { water level } \\
\text { (feet/year) }\end{array}$ & $\begin{array}{c}\text { Median annual } \\
\text { decline (-) in } \\
\text { water level } \\
\text { (feet/year) }\end{array}$ \\
\hline Craighead & 3 & -0.84 to -0.69 & -0.77 & -0.77 \\
Crittenden & 8 & -1.83 to -0.99 & -1.39 & -1.39 \\
Greene & 2 & -0.47 to -0.07 & -0.27 & -0.27 \\
Lee ${ }^{1}$ & 1 & -1.64 & -1.64 & -1.64 \\
Mississippi & 9 & -1.68 to -0.58 & -1.00 & -0.84 \\
Poinsett & 4 & -1.53 to -0.17 & -0.82 & -0.79 \\
St. Francis & 1 & -1.57 & -1.57 & -1.57 \\
\hline
\end{tabular}

${ }^{1}$ County produced one hydrograph of 20 years or more. 


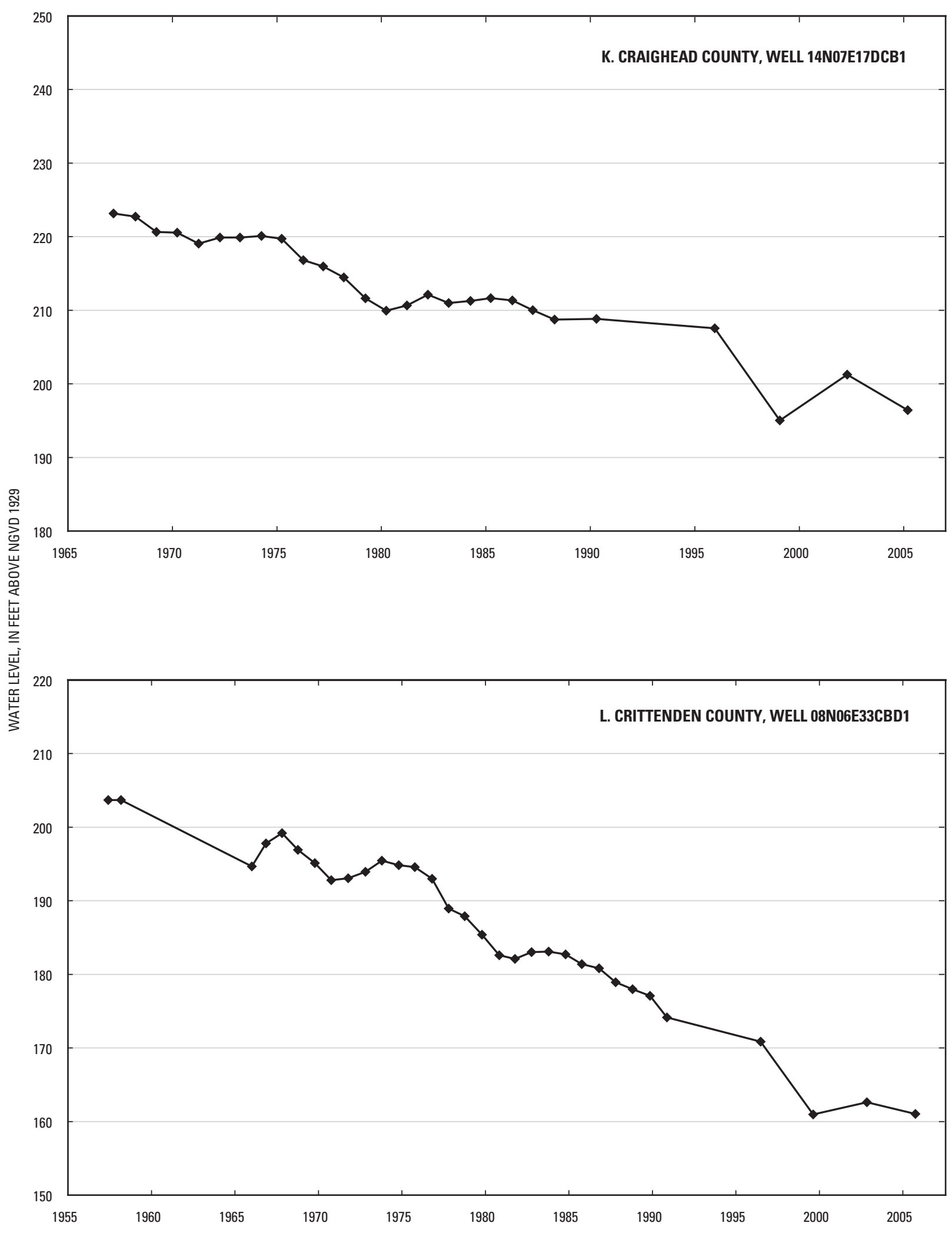

Figure 9. Water-level hydrographs for selected wells completed in the Wilcox aquifer in northeastern Arkansas. 


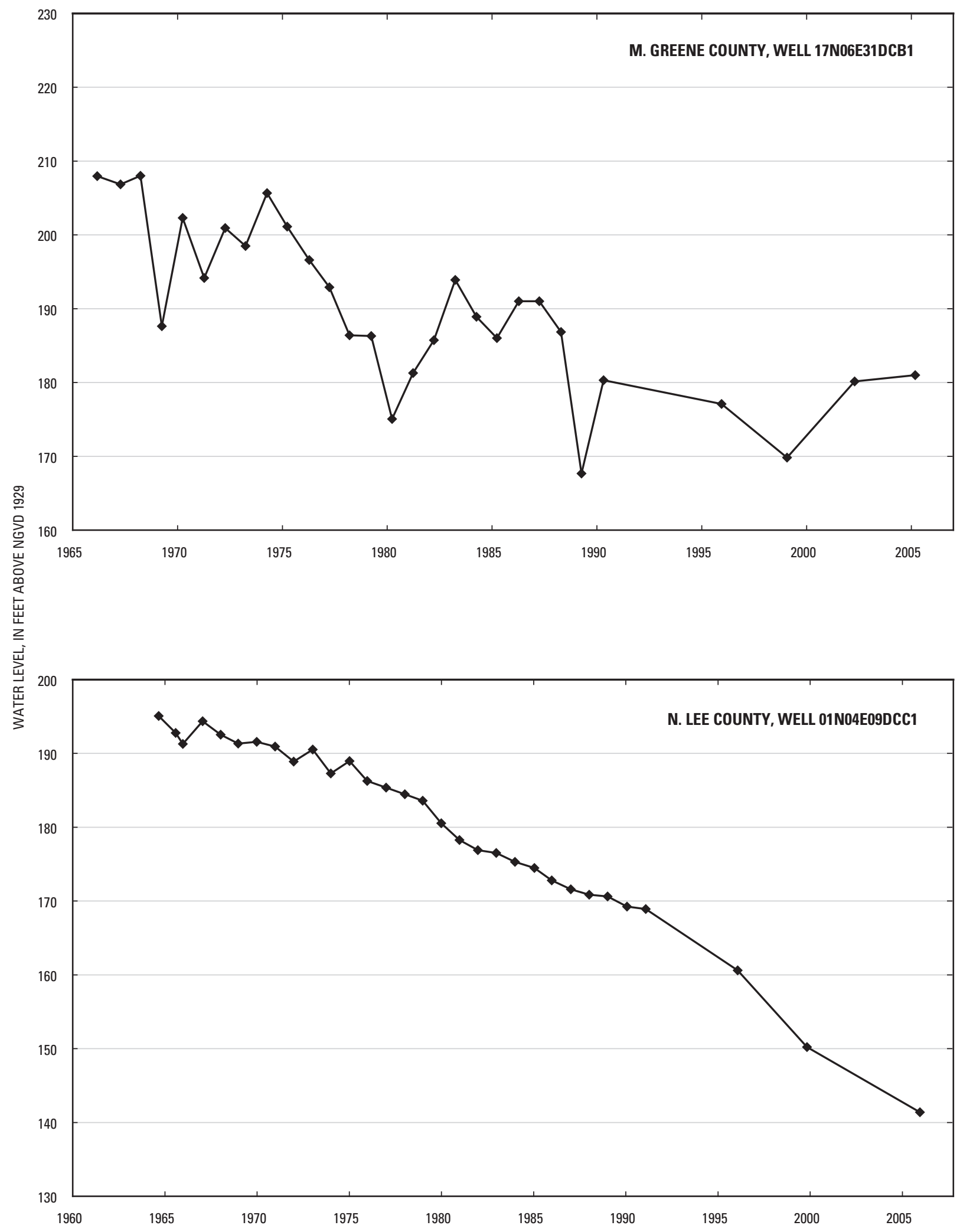

Figure 9. Water-level hydrographs for selected wells completed in the Wilcox aquifer in northeastern Arkansas.-Continued 


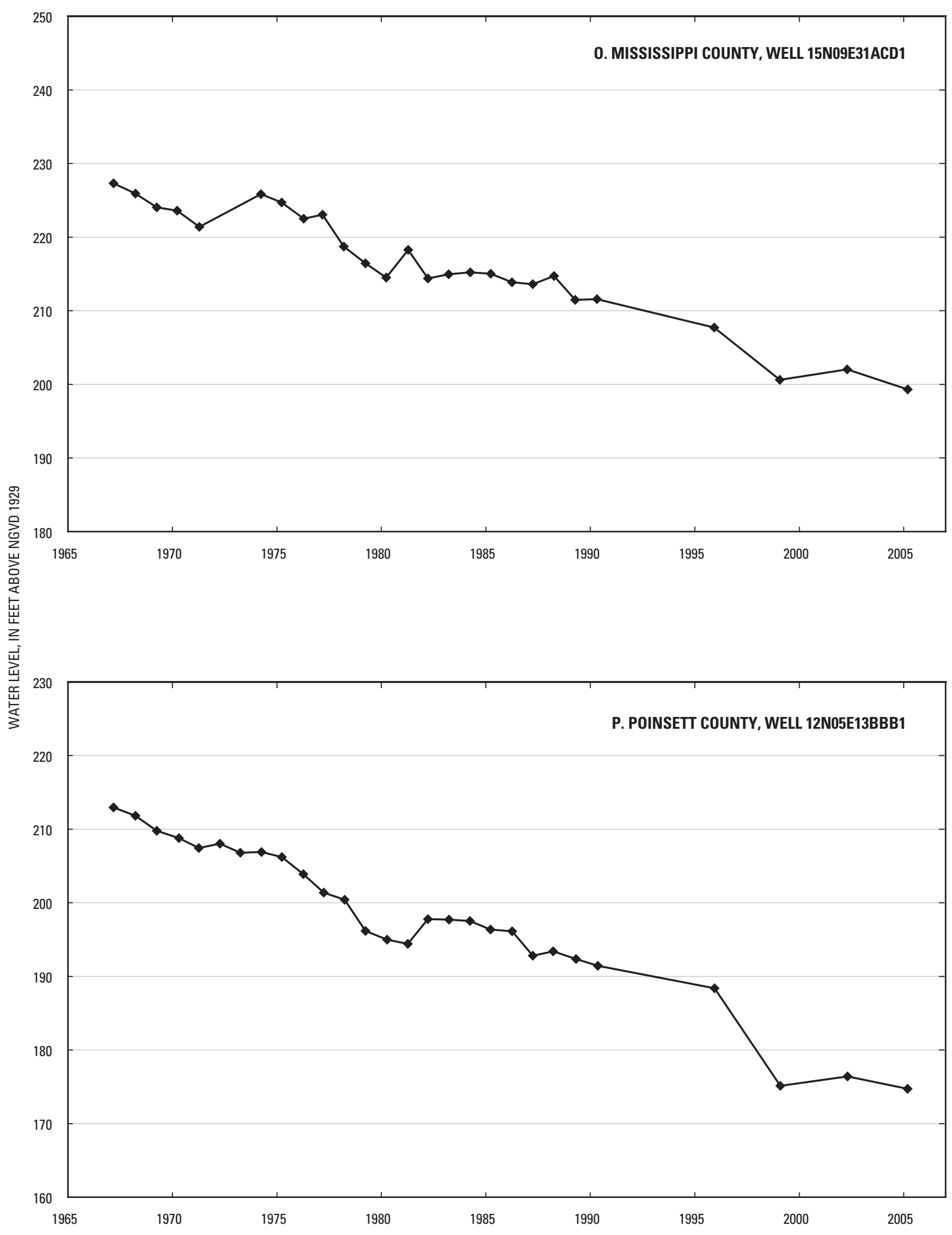

Figure 9. Water-level hydrographs for selected wells completed in the Wilcox aquifer in northeastern Arkansas.-Continued 


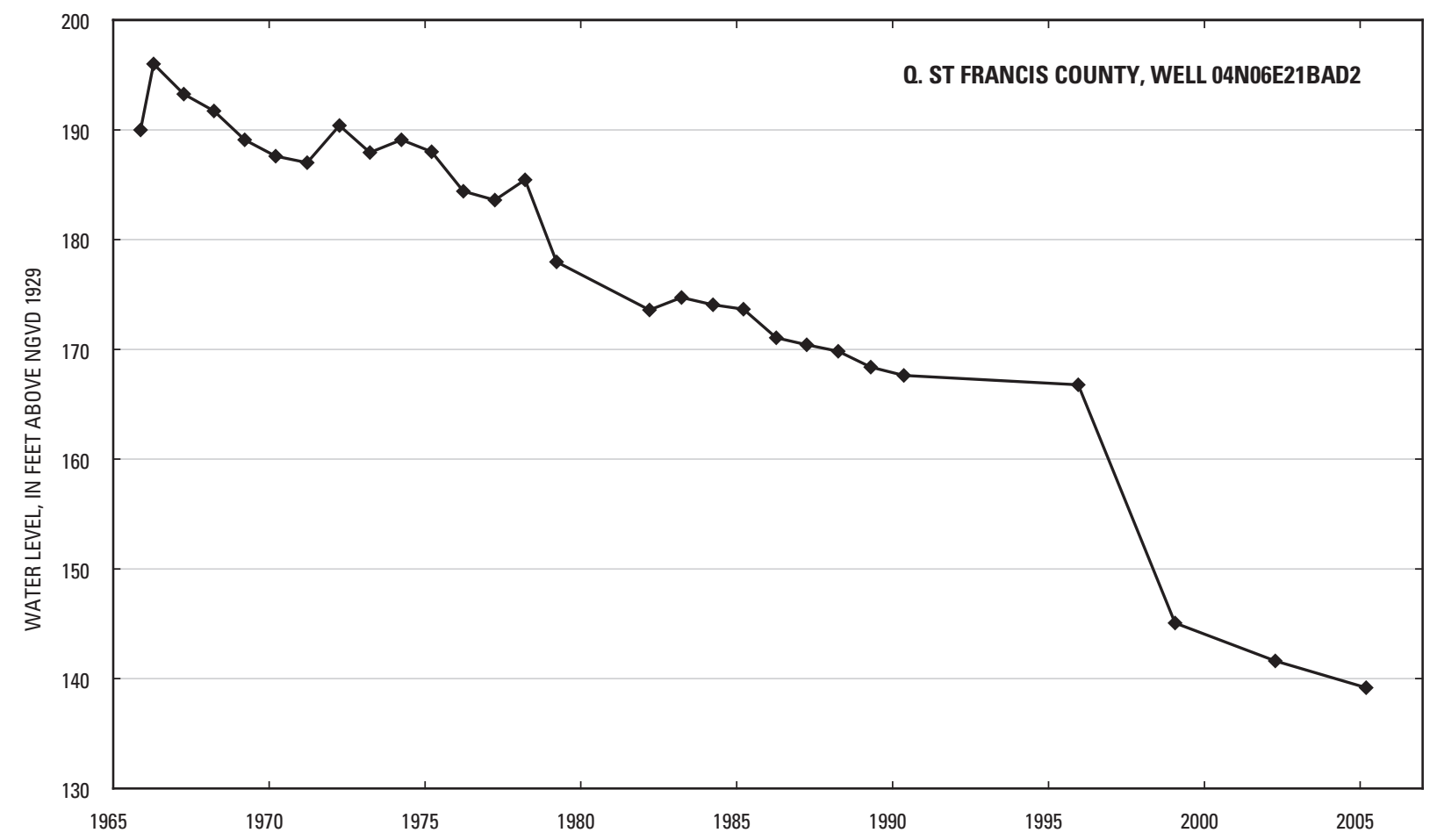

Figure 9. Water-level hydrographs for selected wells completed in the Wilcox aquifer in northeastern Arkansas.-Continued

\section{Summary}

The Cockfield aquifer and the Wilcox aquifer provide sources of ground water in southern and northeastern Arkansas. In 2000 about $9.9 \mathrm{Mgal} / \mathrm{d}$ was withdrawn from the Cockfield aquifer and about $22.2 \mathrm{Mgal} / \mathrm{d}$ was withdrawn from the Wilcox aquifer. Major withdrawals from the aquifers were for industrial and public water supplies, with lesser but locally important withdrawals for domestic and livestock uses.

A study was conducted by the U.S. Geological Survey in cooperation with the Arkansas Natural Resources Commission and the Arkansas Geological Survey to determine the water level associated with the Cockfield aquifer and the Wilcox aquifer in southern and northeastern Arkansas. During February and March 2006, 56 water-level measurements were made in wells completed in the Cockfield aquifer and 59 water-level measurements were made in wells completed in the Wilcox aquifer, 16 in southwestern and 43 in northeastern Arkansas. This report presents the results as potentiometric-surface maps and as long-term water-level hydrographs.

The Cockfield Formation is Eocene age and generally consists of discontinuous fine- to medium-grained sand units interbedded with silt, clay, and lignite, all of nonmarine origin, in southeastern Arkansas. Most of the sand beds constitute the Cockfield aquifer and are near the base of the Cockfield
Formation. The Cockfield Formation generally ranges from 100 to $400 \mathrm{ft}$ thick near the outcrop area and thickens downdip of the outcrop area reaching $625 \mathrm{ft}$ thick in northeastern Chicot County. Total sand thickness in the Cockfield Formation generally ranges from 20 to $150 \mathrm{ft}$. Withdrawals from the Cockfield aquifer in the study area during 2000 totaled about 9.9 Mgal/d. Withdrawals from the Cockfield aquifer generally increased from 1975 to 2000 , the exception being a decrease in 1985 , producing 5.2 Mgal/d in 1975, 7.2 Mgal/d in 1980, 5.0 $\mathrm{Mgal} / \mathrm{d}$ in 1985, 8.1 Mgal/d in 1990, and 9.8 Mgal/d in 1995. Most wells completed in the Cockfield aquifer study area provide small volumes of water for domestic and livestock use.

The potentiometric-surface map shows the altitude of the water surface in tightly cased wells screened in the Cockfield aquifer. The regional direction of ground-water flow generally is towards the east and southeast, away from the outcrop, except in areas of intense ground-water withdrawals, such as western Drew County, southeastern Lincoln County, southwestern Calhoun County, and near Crossett in Ashley County. There are three cones of depression indicated by relatively low water levels in southeastern Lincoln County, southwestern Calhoun County and near Crossett in Ashley County. The cones of depression in southeastern Lincoln and southwestern Calhoun Counties were not evident in the 2003 potentiometric-surface map. The lowest water-level altitude measured 
was $44 \mathrm{ft}$ in Lincoln County; the highest water-level altitude measured was $346 \mathrm{ft}$ in Columbia County, at the outcrop area.

Hydrographs from 40 wells with historical water levels from 1986 to 2006 were evaluated using linear regression to calculate the annual rise or decline, in feet per year. Calhoun and Cleveland Counties have mean annual rises from 0.01 to 0.07 ft/yr. Arkansas, Ashley, Bradley, Chicot, Columbia, Drew, Lincoln, and Union Counties have mean annual declines from 0.04 to $0.55 \mathrm{ft} / \mathrm{yr}$. Desha County has a mean annual decline of about $1.35 \mathrm{ft} / \mathrm{yr}$.

The Wilcox Group of Eocene and Paleocene age is located throughout most of southern and eastern Arkansas. There are two study areas in the southwestern and northeastern portions of Arkansas for which potentiometric surfaces of the Wilcox aquifer were made. The Wilcox Group in the southwestern study area consists of interbedded layers of clay, sandy clay, sand, and lignite. Formations in the southwestern study area are undifferentiated. Sand beds generally are thin and are not continuous over large areas. In most of the southwestern study area, the Wilcox Group overlies the Midway Group and is overlain by terrace deposits and alluvium of Quaternary age or crops out in discontinuous bands that are 1 to 3 miles wide. The Wilcox Group becomes progressively thicker downslope from the outcrop, ranging in thickness from a few feet in the outcrop to about $750 \mathrm{ft}$ in northeastern Bradley County.

The Wilcox Group in most of the northeastern study area consists of thin interbedded layers of lignitic sand and clays. The Wilcox Group outcrops at or near Crowleys Ridge in Clay, Greene, and Craighead Counties. East of Crowleys Ridge, the middle to lower part of the Wilcox Group contains a sand bed of $200 \mathrm{ft}$ or more in thickness referred to as the "1,400-foot sand" or the "lower Wilcox aquifer". The Wilcox aquifer in the northeastern study area is confined above by a clay bed of the Wilcox Group and confined below by a clay bed of the Wilcox Group or the Midway Group.

Withdrawals from the Wilcox aquifer in the study areas totaled about 22.2 Mgal/d during 2000, most of which came from the northeastern study area. Withdrawals from the Wilcox aquifer generally increased from 1975 to 1995 , the exception being a decrease in 1985 , producing $24.3 \mathrm{Mgal} / \mathrm{d}$ in $1975,25.7 \mathrm{Mgal} / \mathrm{d}$ in 1980, $21.0 \mathrm{Mgal} / \mathrm{d}$ in 1985, 30.9 Mgal/d in 1990 , and $41.0 \mathrm{Mgal} / \mathrm{d}$ in 1995 .

The potentiometric-surface maps show the altitude of the water surface in tightly cased wells screened in the Wilcox aquifer. The direction of ground-water flow in the southwestern study area generally is south and east, except in Clark County where flow is towards the Ouachita River that has eroded into the Wilcox Group and deposited alluvium. The lowest water-level altitude measured in southwestern Arkansas was $147 \mathrm{ft}$ near the Ouachita River in Clark County; the highest water-level altitude measured was $397 \mathrm{ft}$ in the outcrop area of Hempstead County.

The direction of ground-water flow in the northeastern study area generally is south and east. Ground-water withdrawals may have altered the natural direction of flow near the centers of pumping at Paragould and West Memphis. The lowest water-level altitude measured in northeastern Arkansas was $120 \mathrm{ft}$ near West Memphis in Crittenden County; the highest water-level altitude measured was $368 \mathrm{ft}$ on Crowleys Ridge in Clay County.

Hydrographs from 28 wells in the northeastern study area with 20 years of historical water levels from 1986 to 2006 were evaluated using linear regression to calculate the annual rise or decline, in feet per year, for each well and grouped by county. All 28 wells showed an annual decline from 1986 to 2006. Craighead, Greene, Mississippi, and Poinsett Counties have mean annual declines from 0.27 to $1.00 \mathrm{ft} / \mathrm{yr}$. Crittenden, Lee, and St Francis Counties have mean annual declines from 1.39 to $1.64 \mathrm{ft} / \mathrm{yr}$. The wells in the southwestern study area did not have 20 years of historical data. 


\section{References}

Ackerman, D.J., 1987, Generalized potentiometric surface of the aquifers in the Cockfield Formation, southeastern Arkansas, spring 1980: U.S. Geological Survey WaterResources Investigations Report 87-4212, scale 1:500,000, 1 sheet.

Albin, D.R., 1964, Geology and ground-water resources of Bradley, Calhoun, and Ouachita Counties, Arkansas: U.S. Geological Survey Water-Supply Paper 1779-G, 32 p.

Broom, M.E., and Lyford, F.P., 1981, Alluvial aquifer of the Cache and St. Francis River Basins, northeastern Arkansas: U.S. Geological Survey Open-File Report 81-476, 48 p.

Fenneman, N.M., and Johnson, D.W., 1946, Physical divisions of the United States (Map): Washington, D.C., U.S. Geological Survey.

Halberg, H.N., 1977, Use of water in Arkansas, 1975: Arkansas Geological Commission Water Resources Summary Number 9, 28 p.

Holland, T.W., 1987, Use of water in Arkansas, 1985: Arkansas Geological Commission Water Resources Summary Number 14, $30 \mathrm{p}$.

Holland, T.W., 1993, Use of water in Arkansas, 1990: U.S. Geological Survey Open-File Report 93-48, pamphlet.

Holland, T.W., 1999, Water use in Arkansas, 1995: U.S. Geological Survey Open-File Report 99-188, 1 sheet.

Holland, T.W., 2004, Estimated water use in Arkansas, 2000: U.S. Geological Scientific Investigations Report 2004-5230, $31 \mathrm{p}$.

Holland, T.W., and Ludwig, A.H., 1981, Use of water in Arkansas, 1980: Arkansas Geological Commission Water Resources Summary Number 14, 30 p.

Hosman, R.L., Long, A.T., Lambert, T.W., and others, 1968, Tertiary aquifers in the Mississippi embayment: U.S. Geological Survey Professional Paper 448-D, 29 p.

Hosman, R.L., 1982, Outcropping Tertiary units in southern Arkansas: U.S. Geological Survey Miscellaneous Investigations Series I-1405, 1 sheet.

Hosman, R.L., 1988, Geohydrologic framework, Gulf Coastal Plain: U.S. Geological Survey Hydrologic Investigations Atlas HA-695, 2 sheets.

Joseph, R.L., 1998, Potentiometric surface of the Cockfield aquifer in southeastern Arkansas and the Wilcox aquifers in southern and northeastern Arkansas, October 1996-July 1997: U.S. Geological Survey Water-Resources Investigations Report 98-4084, 19 p.
Onellion, F.E., and Criner, J.H., Jr., 1955, Ground-water resources of Chicot County, Arkansas: Arkansas Geological and Conservation Commission Water Resources Circular No. 3, 27 p.

Petersen, J.C., Broom, M.E., and Bush, W.V., 1985, Geohydrologic units of the Gulf Coastal Plain in Arkansas: U.S. Geological Survey Water-Resources Investigations Report 85-4116, 20 p.

Plebuch, R.O., 1961, Fresh-water aquifers of Crittenden County, Arkansas: Arkansas Geological and Conservation Commission Water Resources Circular 8, 65 p.

Ryling, R.W., 1960, Ground-water potential of Mississippi County, Arkansas: Arkansas Geological and Conservation Commission Water Resources Circular 7, 87 p.

Schrader, T.P., and Joseph, R.L., 2000, Potentiometric surfaces of aquifers in the Cockfield Formation in southeastern Arkansas and the Wilcox Group in southern and northeastern Arkansas, 2000: U. S. Geological Survey WaterResources Investigations Report 00-4206, 22 p.

Westerfield, P.W., 1994, Potentiometric-surface maps of the Cockfield and lower Wilcox aquifers in Arkansas, 1991: U.S. Geological Survey Water-Resources Investigations Report 93-4134, scale 1:500,000, 2 sheets.

Yeatts, Daniel S., 2004, Potentiometric Surfaces in the Cockfield and Wilcox aquifers of southern and northeastern Arkansas, 2003: U.S. Geological Survey Scientific Investigations Report 2004-5169, 24 p. 
For more information concerning the research described in the report:

U.S. Geological Survey Arkansas Water Science Center 401 Hardin Road

Little Rock, AR 72211-3528

(501) 228-3600

http://ar.water.usgs.gov 


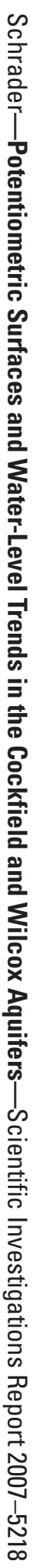

8 Printed on recycled paper 